\title{
Resilience Thinking as a System Approach to Promote China's Sustainability Transitions
}

\author{
Qirui $\operatorname{Li}^{1,2,3,4}$ \\ 1 Climatology Research Group, University of Bayreuth, 95447 Bayreuth, Germany; qirui.li@uni-bayreuth.de \\ 2 Bayreuth Centre of Ecology and Environmental Research, University of Bayreuth, 95448 Bayreuth, Germany \\ 3 State Key Laboratory of Soil Erosion and Dryland Farming on the Loess Plateau, Institute of Water and Soil \\ Conservation, Chinese Academy of Sciences and Ministry of Water Resources, Yangling 712100, China \\ 4 Leibniz Institute of Ecological Urban and Regional Development, 01279 Dresden, Germany
}

Received: 22 April 2020; Accepted: 13 June 2020; Published: 18 June 2020

\begin{abstract}
Urban regeneration and rural revitalization are becoming major policy initiatives in China, which requires new approaches for sustainability transitions. This paper reviewed the history of policy reforms and institutional changes and analysed the main challenges to sustainability transitions in China. The urban-rural systems were defined as a complex dynamic social-ecological system based on resilience thinking and transition theory. The notions of adaptation and transformation were applied to compose a framework to coordinate "resilience" with "sustainability". The findings indicate that China's urbanization has experienced the conservative development of restructuring socio-economic and political systems (before 1984), the fast industrialization and economic development leaned to cities (1984 to 2002), the rapid urbanization led by land expropriation and investment expansion (2002 to 2012), and the quality development transformation equally in urban and rural areas (since 2012). The sustainability transitions have been challenged by controversial institutional arrangements, concerning population mobility control, unequal social welfare, and incomplete property rights. A series of policy interventions should be designed and implemented accordingly with joint efforts of multiple stakeholders and based on the combined technocratic and bottom-up knowledge derived from proactive and conscious individuals and collectives through context-dependent social networks.
\end{abstract}

Keywords: urbanization; rural-urban development; social-ecological systems; transformative changes; adaption and mitigation

\section{Introduction}

Urbanization depicts the movement of rural population to urban areas, the increase of urban population, and the adaptation of rural population toward an urban lifestyle. The resultant socio-economic and bio-physical changes provide opportunities and challenges to sustainability. In China, urbanization has its characteristics and unique pathway with the rapid growth of the national economy, rural to urban migration, city numbers and urban areas [1,2]. For the last four decades, urbanization level and the number of cities in China have increased by $42 \%$ and 479 , respectively. Starting from less than 20\% in 1978, the urbanisation level exceeded the 50\% threshold in 2012 (See Appendix A) and will reach more than 75\% in 2050 [3-5]. Such rapid urbanization has involved a set of state actions on policy reforms and institutional changes about development strategies and factor markets such as land, labour, and capital $[2,6]$. Reform and change occur when the benefits exceed the costs of changing government rules and processes $[7,8]$. Thus, revisiting the policy reforms and institutional changes over time is vital to understand China's urbanization and explore sustainable solutions. 
By reviewing previous studies, this paper attempts to investigate the change in state policies and institutions about urban-rural development, environmental conservation, land management, labour use, science and technology, and economic activities and financial strategies along with the process of urbanization since 1949. It is hypothesized that the implemented policy reforms and institutional changes generated both desirable and undesirable outcomes. The failure of establishing institutions and markets (e.g., uncertain property rights) derive undesirable outcomes (e.g., increased transaction costs and negative externalities of public goods) which may challenge China's urbanization. Efforts are hence required to define urban-rural systems (URSs) as a complex coupled system, to clarify the system components and dynamics of China's urbanization, and to provide instrumental approaches and implications for sustainability transitions.

Resilience thinking may contribute a system approach to the study by acknowledging URSs as complex dynamic social-ecological systems (SESs) with human-nature dynamics evolving cross multiple scales over time [9-11]. Resilience depicts the capacity of complex URSs to absorb disturbance, adapt to changing conditions and withstand within the current regime, and cross the threshold into new development trajectories and fundamentally improved state in response to unforeseeable crises and enforced interventions. Linking it to transition theory [12] (pp. 111-114) may help understand how the URSs evolution of technical, economic, social-cultural, and ecological dynamics bring about change towards sustainable development [13]. Thus, it is worthwhile for this paper to attempt to link the resilience thinking and transition theory into a system approach for China's sustainability transitions.

Following this introduction, Section 2 gives an overview of resilience thinking as conceptual grounds. Section 3 reviews the history of policy reforms and institutional changes and explains the main challenges to sustainability transitions in China. Section 4 provides an analytical framework and implications accordingly. Conclusions of this research are demonstrated in Section 5.

\section{Resilience of Urban-Rural Systems}

\subsection{Rationale of Resilience Thinking}

Resilience is the capacity of a system to retain its usual function, structure, identity, and feedbacks after undergoing change, absorbing disturbance, and reorganising behaviour $[9,10]$. Urban and rural systems (URSs) are hence treated as coupled SESs with human-nature dynamics evolving cross multiple scales over time. As shown in Figure 1, absorption leads to persistence of the status quo through the capacity to take intentional protective action and strategies to cope with unknown shocks and stress instead of reducing future shocks and stress; adaptation refers to incremental adjustments and better management within the current regime in response to changing conditions, increasing system stability while reducing future shocks and stress, and; transformation instigates fundamental changes in the nature of a system to address the underlying failures of development or imbalances, which is about the capacity to cross the threshold into new development trajectories [10,14-17]. Within this conceptualization, system feedbacks are emphasized as they determine and underpin the changing conditions, trajectories, and interactions across scales while feedbacking to and refining the intervention for desired effects and outcomes in the future $[17,18]$. 


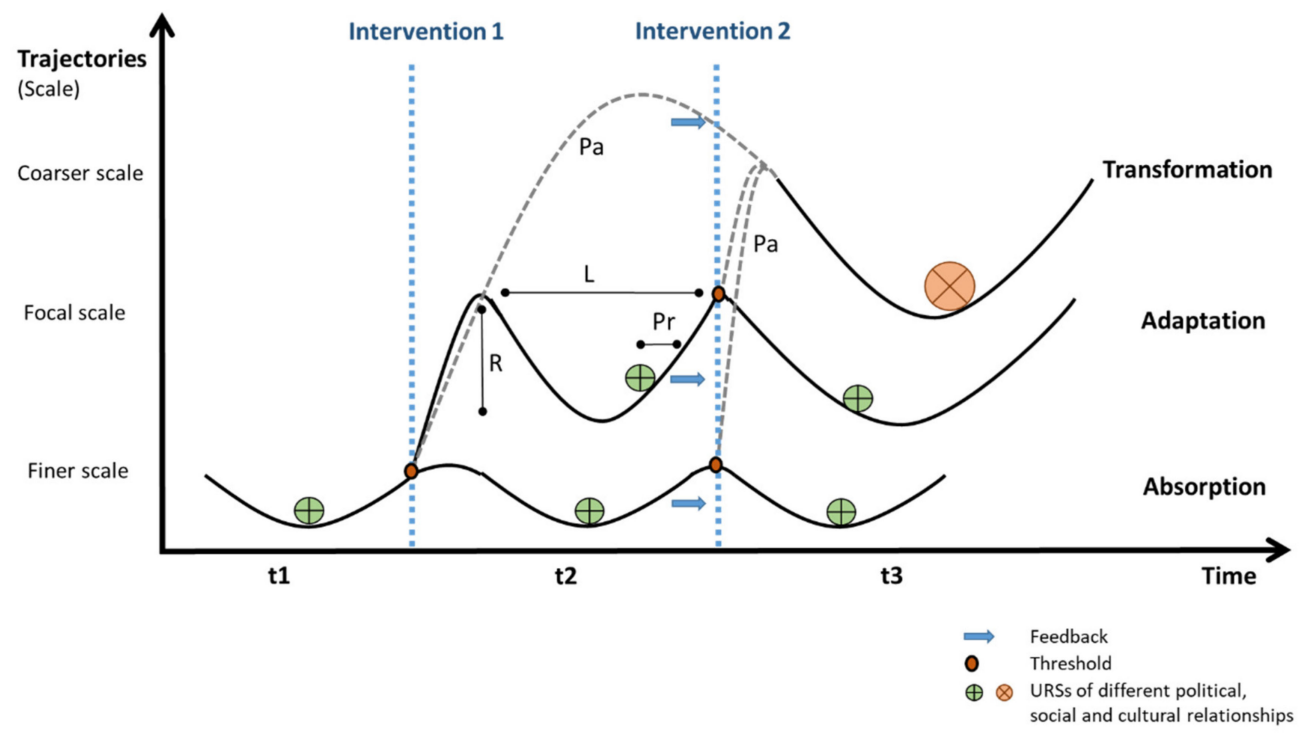

Figure 1. Resilience building of urban-rural systems (URSs) during the transition (adapted from $[10,19,20])$. Note: the dashed line in grey means alternative trajectories. Latitude (L) is the maximum change of a system before evolving or collapse; resistance $(R)$ refers to the difficulty of a system to be changed; precariousness (Pr) means the distance of the current state of a system to an evolving or collapsing threshold, and; panarchy (Pa) depicts the cross-scale interaction among URSs [10].

Divergent URSs evolve in different development trajectories (i.e., absorption, adaptation, and transformation), with each having unique functions, structures, identities, and feedbacks over time (from $\mathrm{t} 1 \mathrm{to} \mathrm{t} 3$ ). This can link resilience thinking to transition theory [12] (pp. 111-114). By looking at URSs transition from a multi-level perspective, notions of absorption, adaptation and transformation help investigate the human-nature interactions across scales [21]. The focal scale refers to understanding the current state, actions, strategies and functions of URSs at a meso level; the finer scale means a deep understanding of URSs patterns, components and dynamics at a micro level, and; the coarser scale represents the dynamics and interactions operating at URSs or cultural, economic and political subsystems at a macro level [22]. The understanding of the URSs transition processes with relevant concepts (e.g., livelihood resource, path dependency, and social memory) can define system function, structure, identity, and feedbacks while linking past pathways with current challenges and presaging future transitional processes. In any given transition, thresholds indicate the key stages and the starting point for the next transition [23]. When disruptive change and system transformation get involved, it is also vital to identify leverage points [24] which are places in URSs' structure where a solution element and innovations can be applied to strengthen or reset identity, navigate feedbacks, and improve functions. By applying system thinking and focusing on the dynamics and drivers of change, the URS framework and concepts may support the building of urban-rural resilience and the formation of innovation, policies, and management towards sustainable transitions.

\subsection{Adaptation and Transformation as the Key to Sustainability Transitions}

Based on the resilience thinking, coupled URSs are defined for a comprehensive understanding and planning. The Dual Sector Model theory [25] indicates that a developing economy like China has been undertaking the labour transition between the traditional agricultural sector and the modern industrial sector during its urbanization process. Thus, the system needs to build resilience towards sustainability transitions (Figure 2) through its adaptive capacities such as learning to live with change and uncertainty (e.g., alteration), nurturing diversity for self-reorganization and self-renewal (e.g., diversification), combining knowledge for learning and experimenting (e.g., intensification), and creating outside opportunities for problem-solving (e.g., non-farm labouring and upscaling) [19,26]. 
On one hand, it may absorb the surplus-labour and other kinds of resources, promote industrialization, and stimulate sustained urban-rural development. On the other hand, the failure of the adaptation may 'trap' the vulnerable or poor people, increase domestic-public dichotomy, and generate socio-economic inequality. When the system got locked in a trap, adaptive management could be helpless $[14,27,28]$. For instance, rapid population growth, industrialization, and shifts to urban lifestyles and consumer demands have led to an ever-increasing demand for water resources in Beijing who relies on nonlocal ecosystem services and non-ecosystem-based production [29]. In such a case, external and internal stresses and disturbance would offset the desired effects and outcomes of intervention approaches, such as spatial upscaling of resource use. It would then need to build system resilience through transformative capacity that alters societal functioning and avoid system collapse and crisis $[10,11,16,30]$. Transformation may react slowly as an accumulation of incremental adaptations [31], or take place rapidly with substantial innovations in technology and fundamental changes [32,33]. In the process of transformation, leverage points are vital to apply innovations and fundamental changes to transform the system, navigate feedbacks, and correct loops [24].

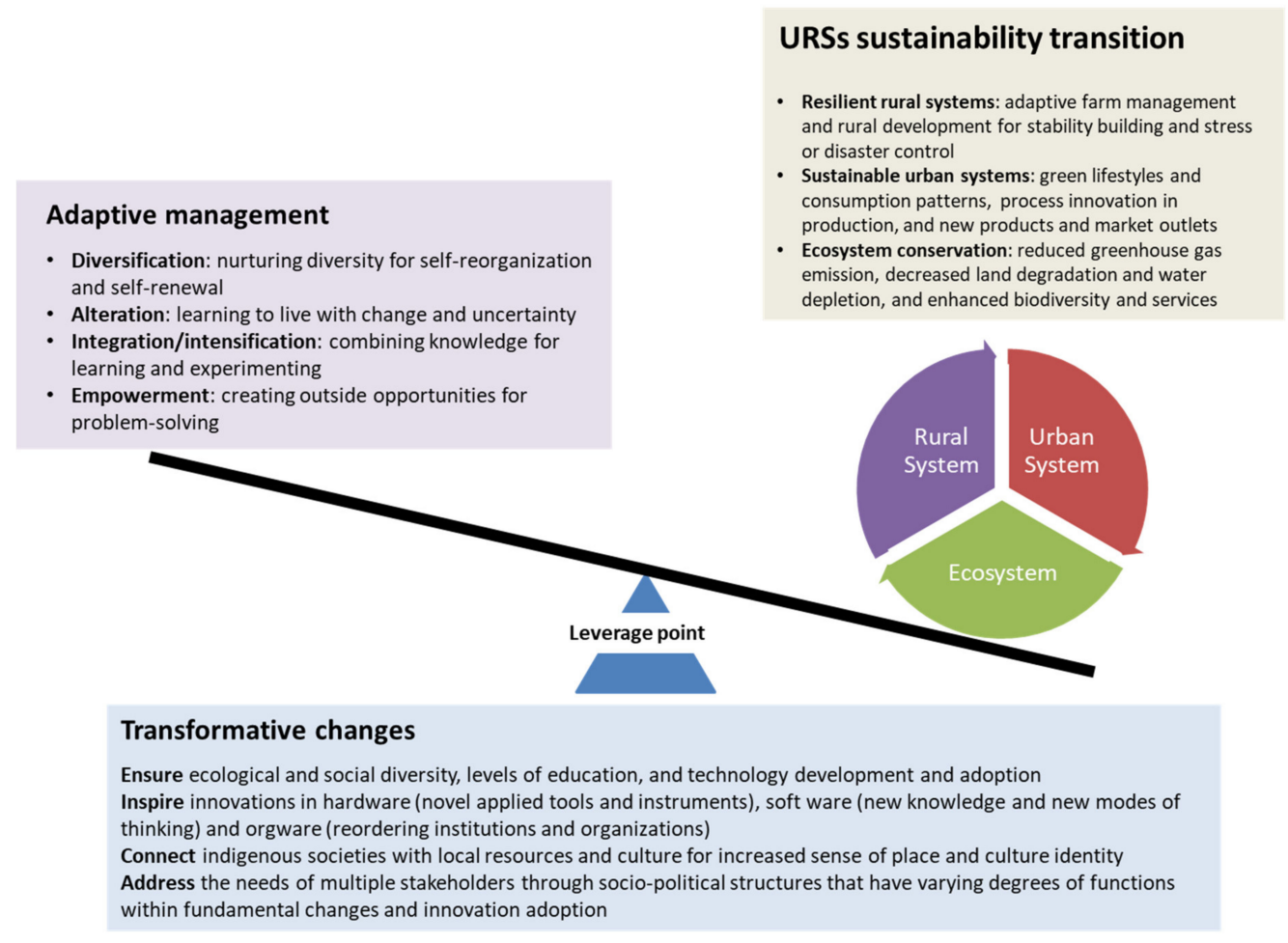

Figure 2. URSs' adaptation to changes and their transformation towards sustainability.

From an evolutionary perspective, innovations are successful novelties of hardware (applied tools and instruments) with software (knowledge and thinking) and orgware (institutions and organizations) which compete in a dynamic selection environment [34,35]. As defined by Freeman and Perez [36], incremental innovations occur continuously as 'learning by doing' outcomes of users' inventions and improvements; radical or disruptive innovations are discontinuous inventions that replace the existing design, process or system with something entirely new; technological innovations are far-reaching changes and improvements in technology creating a new range of products and services affecting more than one branches of the system, and; technological revolutions are a combination of technological innovations which can affect the behaviour and structure of the entire system [22]. Technology development and adoption are the sources of innovations which is the subset of the system that generate novelties and create new social relationships [37]. Definitions and identifications of various novelties and their associated innovations within URSs may help understand social technological motivations and develop pathways towards sustainability. 
Referring to transition theory [12] (pp. 111-114)fundamental changes for transformation appear in system identify, structure, functions, and feedback within a given period. System identity is defined by key components (e.g., objects, agents, entities) that make up the system, the relationships or networks between components that describe how system components interact or fit together, and their continuity to maintain stable through space and time [37-39]. Hence, system identity is the essential element to understand URSs resilience and their drivers and barriers, dynamics of innovation and interactions, and potential alternative sustainability pathways. Identity can be quantitatively defined to the boundaries (or thresholds) of a stability domain of attraction [9], which may involve qualitative changes based on human interests and values. In URSs, human identity and cultural identity need particular attention to how people understand who they are, their role in society, their relation to the environment, and their feeling of belonging to a group [40,41]. Sense of place that is represented by place attachment [42] and place identity [43] and place meanings [44], convey connections between people, place and nature [45-47]. It helps understand identity in adaptation and transformation, in addition to innovation, memory (e.g., elderly people and socio-biological legacies), self-organization (i.e., the formation of patterns due to social-ecological interactions) [37,48]. Moreover, the indigenous societies in URSs are embedded into local ecosystems and their relationships with local resources have shaped the system identity, agent, culture, governance institutions, and interactions [49]. Thus, an analysis of system structure through actors (e.g., civil society and NGOs), institutions (e.g., rules, laws, customs and routines), interactions (e.g., networks) and infrastructure (e.g., machines, subsidies and knowledge) [50], may provide insight into the drivers and barriers for URSs' innovations and fundamental changes. This can be further promoted by analysing system functions that contribute to systemic development and innovation adoption through entrepreneurial activities (e.g., commercial projects), knowledge development (e.g., studies and laboratory trials), knowledge diffusion and exchange (e.g., conferences and workshops), policy guidance, market formation and selection (e.g., tax and subsidy), resource mobilisation (e.g., investments), support from advocacy coalitions (e.g., lobbies) [22,51]. The URSs functions may be qualitative and/or quantitative depending on the nature and quantity of identity components and system structure that contribute to the function. Changes in the function may reinforce (positive feedback) or modify (negative feedback) subsequent interventions and behaviour. Therefore, a systematic understanding and clarification of the fundamental changes in system identity, structure, functions, and feedback may facilitate transition management towards sustainability.

\section{Policy Reforms and Institutional Changes Driving China's Urbanization}

\subsection{Four Periods of China's Urbanization since 1949}

Review of the literature (see Appendix B) indicates that China's urbanization has experienced four divergent periods (Figure 3) along with the policy reforms and institutional changes since 1949 (Table 1). The initial period of conservative development (before 1984) focused on recovering national economy and restructuring socio-political systems. Besides an equal allocation of farmland to peasants, household registration system ('hukou') initiated in 1958 laid up urban-rural disparity for the future. It divided the population into agricultural (or rural) and non-agricultural (or urban) and stipulated that everyone must have permanent household registration in only one place. In 1984, the URSs were at a tipping point [52], where rural labour could enter the cities while China's first national regulation of urban planning and management being enacted $[53,54]$. It was followed by the period of urbanization with fast industrialization and economic development in cities (1984 to 2002). During that period, a series of reforms were undertaken to support the development of small cities and towns concerning land administration, property rights and markets, fiscal systems, foreign direct investments, and so on. After joining the World Trade Organization in 2001, the 2002 'coordinated urban-rural development' became a national strategy. The URSs were hence near the threshold for a critical transition towards the rapid urbanization led by land expropriation and investment expansion 
(2002 to 2012). A set of institutional changes and policy reforms were implemented to stimulate the rapid growth of the service sector, fixed-asset investments via governments' stimulus package and export-oriented manufacturing driven by FDI. The dependence on land revenue and infrastructure investment left China with an excess of industrial overcapacity, inefficient land use and overexpansion of urban boundaries, large corporate debts, and a growing urban-rural disparity. Thus, regulations and institutions were introduced during the new period of quality development in both urban and rural areas (2012 to present). Since 2012, 'new rural construction' and 'rural revitalization' have been equally emphasized with urban redevelopment as a national strategy to stimulate domestic consumption while constraining urban expansion. The 2015 Supply-side Structural Reform was implemented to reduce production capacity and de-stock property inventories while promoting the service sector, in addition to a set of policy supports on agricultural production, rural infrastructure development, and land management (See Appendix B).

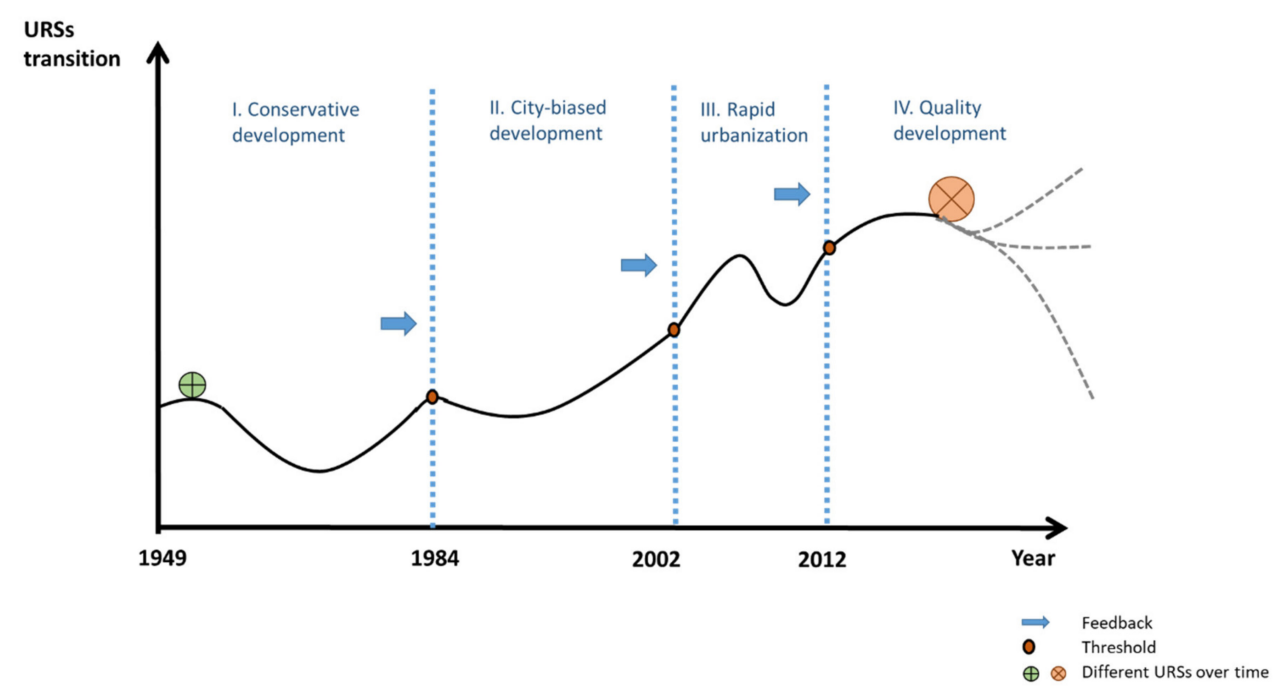

Figure 3. Urban transitions in China since 1949. Note: the dashed line in blue depicts the key policy interventions which lead to critical transitions, whereas the one in grey indicates potential trajectories in the future.

The four periods of China's urbanization were driven by different institutional changes and policy reforms, which demonstrate various development trajectories of divergent URSs. Each of the URSs has specific architectural features and unique functions, which gives feedbacks to and finetunes the policy and institution interventions to navigate risks and opportunities in the future. As to the future, China's transformation to quality development is impeded by the urban-rural dichotomy as a result of institutional constraints, such as restrictions on 'hukou' [55], differentiated land ownerships and social welfare provision [56], and incomplete property rights [57,58].

In this paper, urbanization refers to the movement from the countryside to cities in terms of land, population, capital, and other resources (see Appendix $C$ ). The period of rapid urbanization has the largest annual growth of urbanization level (See Appendix A) of about $1.23 \%$ that is followed by the period of quality management $(1 \%)$, city-biased development $(0.85 \%)$, and conservative development (0.73\%). From 1978 to 2019, urban and rural incomes (see Appendix D) increased by $1000 \mathrm{RMB}$ and $378 \mathrm{RMB}$ per year, respectively, with the income difference (i.e., the ratio of urban income to rural income) remained at around 2.6. As the growth rate of urbanization level, the highest difference between urban and rural incomes was seen during the period of rapid urbanization with a mean value of 3.04. It is followed by a period of quality management (2.74), city-biased development (2.46), and conservative development (2.31). The variation of population shift and economic incomes is in line with the defined four periods, which tested the plausibility of the assumptions about the history of policy reforms and institutional changes. 
Table 1. Major policies and reforms along the process of China's urbanization since 1949.

\begin{tabular}{|c|c|c|c|c|}
\hline Period & Year & Urbanization Level (\%) & Key Policies and Reforms & Domain \\
\hline \multirow[t]{8}{*}{$\begin{array}{l}\text { Conservative } \\
\text { development }\end{array}$} & 1950 & 11.18 & $\begin{array}{l}\text { The Land Reform Law of the People's Republic of China } \\
\text { transferred land ownership to the peasant class, by which } \\
\text { farmers gained land ownership while the allocation of farmland } \\
\text { was equalized. This formed an equalized environment for } \\
\text { agricultural development and the industrialization of China } \\
\text { [59] (pp. 34-35). }\end{array}$ & Land management \\
\hline & 1952 & 12.46 & $\begin{array}{l}\text { The 1st Five-year Plan (1953-1957) promoted heavy-industry } \\
\text { factories in the planned economy; rural population were } \\
\text { encouraged to immigrate for employment opportunities in } \\
\text { cities, especially in the western part of China; science and } \\
\text { technology (S\&T) policy nevertheless concentrated on military } \\
\text { defences, such as space conquest and atomic bombs [60-62]. }\end{array}$ & $\begin{array}{l}\text { Economic activities and } \\
\text { financial strategies; Labour } \\
\text { management; Science and } \\
\text { technology }\end{array}$ \\
\hline & 1958 & 16.25 & $\begin{array}{l}\text { The Household Registration System (hukou) was introduced, } \\
\text { which divided the population into agricultural (or rural) and } \\
\text { non-agricultural (or urban), prohibited free rural-to-urban } \\
\text { migration, and controlled population movement [63]. }\end{array}$ & Labour management \\
\hline & 1961 & 19.29 & $\begin{array}{l}\text { The Readjustment, Consolidation, Strengthening, } \\
\text { and Improvement was implemented to prioritize agriculture } \\
\text { and light industries while reducing urban population. }\end{array}$ & $\begin{array}{l}\text { Economic activities and } \\
\text { financial strategies; Labour } \\
\text { management }\end{array}$ \\
\hline & 1966 & 17.86 & $\begin{array}{l}\text { The Great Proletarian Cultural Revolution compressed the } \\
\text { industrialization, technological development, and urbanization } \\
\text { processes. }\end{array}$ & Political activities \\
\hline & 1979 & 18.96 & $\begin{array}{l}\text { The Household Responsibility System was adopted, by which } \\
\text { local managers are held responsible for the profits and losses of } \\
\text { an enterprise. }\end{array}$ & $\begin{array}{l}\text { Economic activities and } \\
\text { financial strategies }\end{array}$ \\
\hline & & & $\begin{array}{l}\text { The Law of the People's Republic of China on Chinese-foreign } \\
\text { Equity Joint Ventures was enacted to expand international } \\
\text { economic co-operation and technological exchange [64]. }\end{array}$ & $\begin{array}{l}\text { Economic activities and } \\
\text { financial strategies; Science and } \\
\text { technology }\end{array}$ \\
\hline & 1982 & 21.13 & $\begin{array}{l}\text { The Constitution was amended to allow the use of foreign } \\
\text { investment for an export-oriented economy. }\end{array}$ & $\begin{array}{l}\text { Economic activities and } \\
\text { financial strategies }\end{array}$ \\
\hline
\end{tabular}


Table 1. Cont.

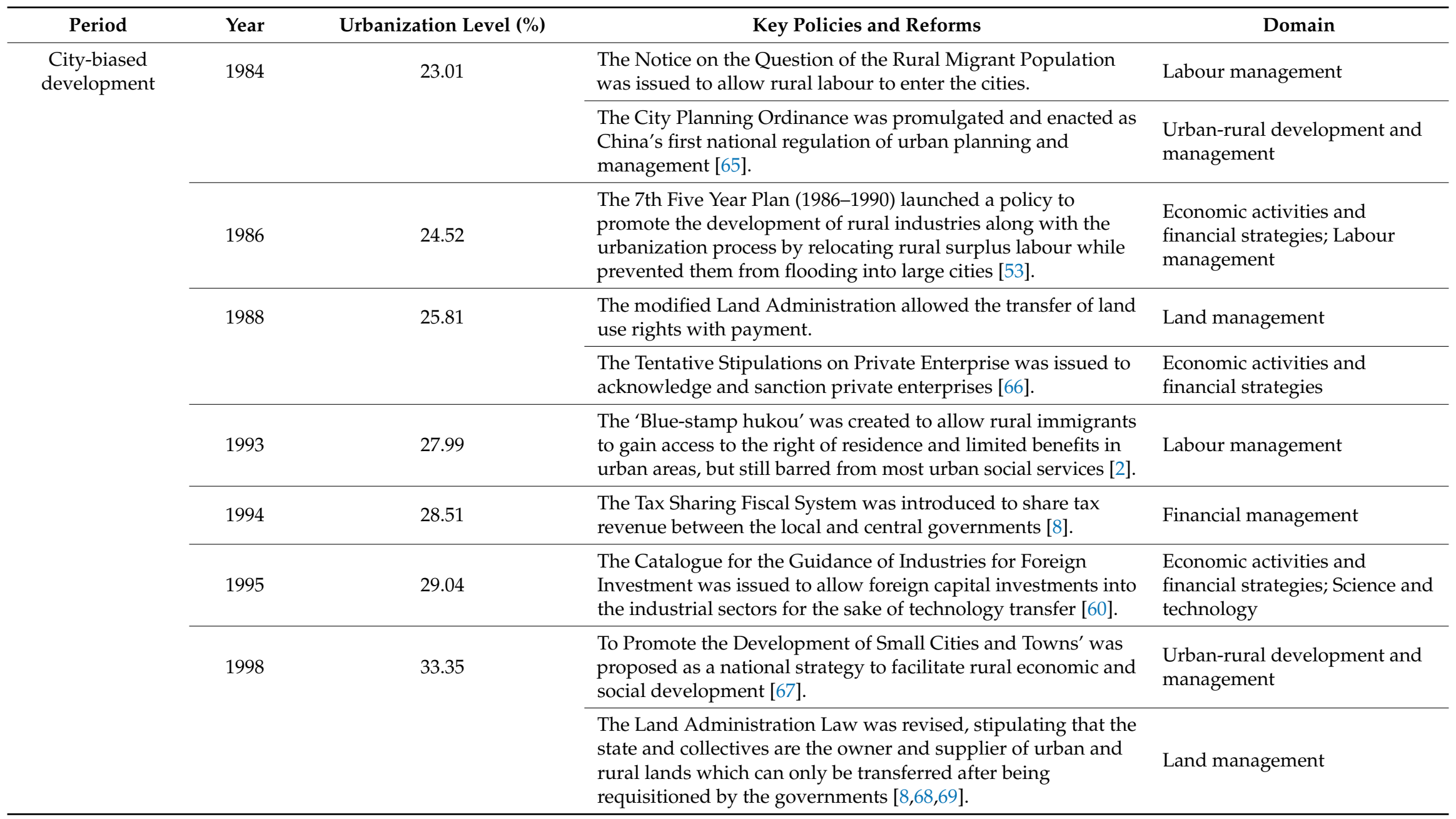


Table 1. Cont.

\begin{tabular}{|c|c|c|c|c|}
\hline Period & Year & Urbanization Level (\%) & Key Policies and Reforms & Domain \\
\hline & \multirow[t]{2}{*}{2000} & \multirow[t]{2}{*}{36.22} & $\begin{array}{l}\text { The Opinions on Promoting the Development of Small Towns } \\
\text { provided guidance and strategies for urban planning and } \\
\text { development in small cities and towns. Urbanization rate was } \\
\text { measured by urban 'hukou' population and rural migrants in } \\
\text { urban employment for more than half a year [70]. }\end{array}$ & $\begin{array}{l}\text { Urban-rural development and } \\
\text { management }\end{array}$ \\
\hline & & & $\begin{array}{l}\text { The rural tax and fee collection system were reformed to reduce } \\
\text { the tax and fee burdens of rural residents. }\end{array}$ & $\begin{array}{l}\text { Economic activities and } \\
\text { financial strategies }\end{array}$ \\
\hline & 2001 & 37.66 & $\begin{array}{l}\text { The Agreement on Trade-Related Aspects of Intellectual } \\
\text { Property Rights was released to enforce intellectual property } \\
\text { rights. }\end{array}$ & $\begin{array}{l}\text { Economic activities and } \\
\text { financial strategies }\end{array}$ \\
\hline \multirow[t]{3}{*}{$\begin{array}{l}\text { Rapid } \\
\text { urbanization }\end{array}$} & 2002 & 39.09 & $\begin{array}{l}\text { The Coordinated Urban-rural Development Strategy declared } \\
\text { that socio-economic development must incorporate urban and } \\
\text { rural areas alike [71]. }\end{array}$ & $\begin{array}{l}\text { Urban-rural development and } \\
\text { management }\end{array}$ \\
\hline & 2003 & 40.53 & $\begin{array}{l}\text { A strict land quota system was introduced to restrain local } \\
\text { governments from requisition new land in large cities and to } \\
\text { encourage urban redevelopment. }\end{array}$ & Land management \\
\hline & 2004 & 41.76 & $\begin{array}{l}\text { The Notice for Further Understanding the Enforcement and } \\
\text { Supervision over Assigning the Right to the Use of the } \\
\text { State-owned Land by Bid Invitation, Auction and Listing } \\
\text { specified that all lands for operation shall be assigned by the } \\
\text { bid invitation, auction and listing system nationwide. }\end{array}$ & Land management \\
\hline
\end{tabular}


Table 1. Cont.

\begin{tabular}{|c|c|c|c|c|}
\hline Period & Year & Urbanization Level (\%) & Key Policies and Reforms & Domain \\
\hline & \multirow[t]{6}{*}{2006} & \multirow[t]{6}{*}{44.34} & $\begin{array}{l}\text { The Medium- to Long-term Plan for Science and Technology } \\
\text { Development (2006-2020) was released to further stimulate the } \\
\text { economy by encouraging technological progress and } \\
\text { innovation. }\end{array}$ & Science and technology \\
\hline & & & $\begin{array}{l}\text { All lands for industrial use was covered by the bid invitation, } \\
\text { auction, and listing system for the first time. }\end{array}$ & Land management \\
\hline & & & $\begin{array}{l}\text { A national 'red line' was set to maintain a minimum of } 120 \\
\text { million ha of arable land to ensure long-term food security } \\
{[72,73] \text {. }}\end{array}$ & Land management \\
\hline & & & $\begin{array}{l}12 \text { of the } 31 \text { provinces in China eliminated the classification } \\
\text { division between agricultural and non-agricultural hukou. }\end{array}$ & Labour management \\
\hline & & & $\begin{array}{l}\text { The agricultural tax was abolished to bring prosperity to rural } \\
\text { areas and coordinate the urban-rural development. }\end{array}$ & $\begin{array}{l}\text { Economic activities and } \\
\text { financial strategies }\end{array}$ \\
\hline & & & $\begin{array}{l}\text { The National Urban System Plan proposed city clusters as } \\
\text { institutionalized governance coordination and cooperation } \\
\text { mechanisms across local administrations. }\end{array}$ & $\begin{array}{l}\text { Urban-rural development and } \\
\text { management }\end{array}$ \\
\hline & \multirow[t]{3}{*}{2008} & \multirow[t]{3}{*}{46.99} & $\begin{array}{l}\text { A } 4 \text { trillion RMB stimulus package was announced to stimulate } \\
\text { infrastructure and the real estate market. }\end{array}$ & $\begin{array}{l}\text { Economic activities and } \\
\text { financial strategies }\end{array}$ \\
\hline & & & $\begin{array}{l}\text { The Urban and Rural Planning Law emphasized the } \\
\text { urban-rural integration. }\end{array}$ & $\begin{array}{l}\text { Urban-rural development and } \\
\text { management }\end{array}$ \\
\hline & & & $\begin{array}{l}\text { Megacities such as Shanghai and Shenzhen offered permanent } \\
\text { residence with a scoring system [2]. }\end{array}$ & Labour management \\
\hline & 2009 & 48.34 & $\begin{array}{l}\text { The Tradable Development Quotas were employed by which } \\
\text { the land converted for urban construction was balanced by } \\
\text { restoring equivalent rural construction land }[74,75] \text {. }\end{array}$ & Land management \\
\hline
\end{tabular}


Table 1. Cont.

\begin{tabular}{|c|c|c|c|c|}
\hline Period & Year & Urbanization Level (\%) & Key Policies and Reforms & Domain \\
\hline \multirow[t]{10}{*}{$\begin{array}{c}\text { Quality } \\
\text { development }\end{array}$} & 2012 & 52.57 & $\begin{array}{l}\text { The eighteenth National Congress proposed to 'strengthen the } \\
\text { overall planning of urban and rural development, enhance the } \\
\text { vitality of rural development, narrow the gap between urban } \\
\text { and rural area.' [76]. }\end{array}$ & $\begin{array}{l}\text { Urban-rural development and } \\
\text { management }\end{array}$ \\
\hline & 2014 & 54.77 & $\begin{array}{l}\text { The National New-Type Urbanization Plan (2014-2020) defined } \\
\text { the new rural construction and urbanization [77]. }\end{array}$ & $\begin{array}{l}\text { Urban-rural development and } \\
\text { management }\end{array}$ \\
\hline & \multirow[t]{3}{*}{2015} & \multirow[t]{3}{*}{56.10} & $\begin{array}{l}\text { The Supply-side Structural Reform was released to readjust the } \\
\text { supply and demand [78]. }\end{array}$ & $\begin{array}{l}\text { Economic activities and } \\
\text { financial strategies }\end{array}$ \\
\hline & & & $\begin{array}{l}\text { The Integrated Reform Plan for Promoting Ecological Progress } \\
\text { was set up to improve environmental conservation and green } \\
\text { development [79]. }\end{array}$ & Environmental conservation \\
\hline & & & $\begin{array}{l}\text { The Opinions on Strengthening Urban-Rural Community } \\
\text { Consultation was issued to establish multi-actor partnerships } \\
\text { and community planning [80]. }\end{array}$ & $\begin{array}{l}\text { Urban-rural development and } \\
\text { management }\end{array}$ \\
\hline & \multirow[t]{4}{*}{2017} & \multirow[t]{4}{*}{58.52} & $\begin{array}{l}\text { The "Lucid waters and Lush Mountains are Invaluable Assets" } \\
\text { movement was initiated to promote green development [81]. }\end{array}$ & Environmental conservation \\
\hline & & & $\begin{array}{l}\text { The 'Rural Revitalization' strategy was put forward as a central } \\
\text { directive on rural development at the 19th National Congress. }\end{array}$ & $\begin{array}{l}\text { Urban-rural development and } \\
\text { management }\end{array}$ \\
\hline & & & $\begin{array}{l}\text { The Promotion Plan for the Readjustment of Inefficient Urban } \\
\text { Land Use was enacted to promote efficient land use in cities and } \\
\text { towns. }\end{array}$ & $\begin{array}{l}\text { Land management; Urban-rural } \\
\text { development and management }\end{array}$ \\
\hline & & & $\begin{array}{l}\text { The Guidance for Strengthening Urban Rehabilitation Work for } \\
\text { Ecological Restoration was issued to modify and renew } \\
\text { ecosystems within cities through nature-based solutions. }\end{array}$ & $\begin{array}{l}\text { Urban-rural development and } \\
\text { management }\end{array}$ \\
\hline & 2018 & 59.58 & $\begin{array}{l}\text { The Rural Vitalization Strategy (2018-2022) released a five-year } \\
\text { plan to improve rural development and governance [83]. }\end{array}$ & $\begin{array}{l}\text { Urban-rural development and } \\
\text { management }\end{array}$ \\
\hline
\end{tabular}


Table 1. Cont.

\begin{tabular}{|c|c|c|c|c|}
\hline Period & Year & Urbanization Level (\%) & Key Policies and Reforms & Domain \\
\hline & \multirow[t]{3}{*}{2019} & \multirow[t]{3}{*}{60.60} & $\begin{array}{l}\text { The New Urbanization Boost stated that cities with a } \\
\text { population under } 3 \text { million should remove all limits on hukou } \\
\text { while restrictions for cities with populations between } 3 \text { million } \\
\text { and } 5 \text { million being relaxed [84]. }\end{array}$ & $\begin{array}{l}\text { Urban-rural development and } \\
\text { management }\end{array}$ \\
\hline & & & $\begin{array}{l}\text { The Guiding Opinions on Strengthening and Improving Rural } \\
\text { Governance was issued and distributed nationwide to build the } \\
\text { governance system and capacity in the countryside [85]. }\end{array}$ & $\begin{array}{l}\text { Urban-rural development and } \\
\text { management }\end{array}$ \\
\hline & & & $\begin{array}{l}\text { The Guidelines for the Development of Modern Metropolitan } \\
\text { Areas introduced the concept of the metropolis [86]. }\end{array}$ & $\begin{array}{l}\text { Urban-rural development and } \\
\text { management }\end{array}$ \\
\hline & 2020 & - & $\begin{array}{l}\text { China's new Foreign Investment Law ensures access to } \\
\text { government procurement markets through fair competition for } \\
\text { foreign-invested enterprises and bans forcing foreign investors } \\
\text { and firms to transfer technology [87]. }\end{array}$ & $\begin{array}{l}\text { Economic activities and } \\
\text { financial strategies }\end{array}$ \\
\hline
\end{tabular}




\subsection{Main Challenges for China's Sustainability Transitions}

The history review (see Appendix B) also indicates that sustainability transitions in China have been challenged by inefficient land use and land management, inadequate city management and administration, and regional and rural-urban disparities.

\subsubsection{Inefficient Land Use and Land Management}

China has experienced fast urban construction since the 1980s [88], with built-up areas increasing from $12,856 \mathrm{~km}^{2}$ in 1990 to $56,225 \mathrm{~km}^{2}$ in 2017 while urban population increasing from 301 million in 1990 to 813 million in 2017 [89]. Between 2000 and 2010 Shanghai expanded by $8.1 \%$ and Beijing by $4.0 \%$ [2]. The increase in built-up areas was attributed to local governments' land requisition and leasing for non-budgetary financial revenue [90]. The contribution of land financing to local governments' total revenue increased from $18.82 \%$ in 2008 to $32.99 \%$ in 2017 [89]. In contrast to countries with private land ownership, China adopted a public land transaction-centred scheme rather than unearned increment capture-cantered land finance in 2000. It helped improve infrastructure [91] but provoked urban expansion and farmland loss [92-94]. As a result, land acquisition increased faster than urban population growth. The population density in the built-up area decreased from $23,413 \mathrm{~km}^{2}$ in 1990 to $14,459 \mathrm{~km}^{2}$ in 2017. Also, land acquisition often provoked legal disputes and rural unrest as some farmers were forced to give up their land [74,95]. The rural migrants without permanent residence called 'floating population' reached 241 million people by 2018 [89]. They have high mobility but uncertain social welfare and limited access to public services in cities. Their temporary and weak connection with the city may lead to weak social ties and an unequal society [96,97]. Due to the prevailing incentives to pursue land-leasing revenue from land financing and land banking, local governments also paid little attention to land use efficiency generating 'empty cities' and high housing prices [98]. Also, the debt that local governments owed to construction investment corporations for infrastructure construction brought high financial risks $[99,100]$. Inefficient land use and land management impede social and financial security and undermine sustainability transitions.

\subsubsection{Inadequate City Management and Administration}

Urban growth fuelled by rural immigration, industrialization, and lifestyle change, has increased the demand for natural resources (e.g., water and soil) and municipal services (e.g., waste disposal and urban transport). However, city management and planning fall behind fast urban growth [99]. Since the tax division reform in 1994, local governments have been operating based on land financing, with many rural land and population moved to urban areas [2]. But the rural population has difficulties obtaining permanent residence and municipal services in the cities [2,101-103]. For instance, informal settlements that rural migrants often live in those metropolitan regions is a challenge for municipal governments due to the associated urban poverty, economic inequality and income vulnerability [2,104,105]. Moreover, the facilities and public services for citizens and safety nets for the poor and the elderly do not meet the increasing demand for life quality [106]. For instance, traffic congestion reduces efficiency in mobility but increase air pollution, deteriorating the quality of life in cities [107-109]. Besides, urban expansion is associated with the decline of farmland and an increase in agricultural land-use intensity. It may impinge protected areas and biodiversity hotspots $[110,111]$ by increasing contamination with an uncontrolled release of gaseous pollutants and wastewater discharge as well as increased nitrate leaching and carbon emission $[29,112,113]$.

\subsubsection{Regional and Urban-Rural Disparities}

Different cities are undergoing different urbanization transitions due to the heterogeneity of labour, capital, land use, and resource efficiency [98,114-117]. The regional disparities demonstrate that some cities have experienced fast economic and demographic growth whereas others shrank from population ageing and ex-migration [116]. Also, urban-rural duality is evident in the modern 
industry in urban areas and traditional agriculture in rural areas [118]; the "floating population" resulted from a delayed migration and settlement, and; the differentiated land ownership and social welfare [56,119]. In particular, the 'hukou' (household registration) system classifies the people into 'city non-agricultural', 'city agricultural', 'rural non-agricultural', and 'rural agricultural' groups [105]. It determines not only the access entitlement to labour markets and social welfare (e.g., public schools and health insurance) but also the land ownership of rural lands (collective ownership) and urban lands (state ownership) $[98,120,121]$. Rural lands cannot be used for capital appreciation due to the collective ownership, the restricted trading and low value of rural homesteads, and the segmentation of the rural land market. Although rural land was expropriated, incomplete property rights often failed to provide landless farmers with market-value equivalent compensation or sound social security access $[74,98]$. This becomes an obstacle to rural land compensation and rental earnings, enlarging the gap between urban and rural incomes and overall inequality [122].

The regional and urban-rural inequality results in the emergence of 'semi-urbanization' and 'regional differences' that is distinct from the pursuit of social integration and sustainable development [123]. It implies that urbanization reform should not only introduce land and fiscal policies but also amend the 'hukou' system to ensure farmers' land use rights, residents' property rights and migrants' equal social welfare. These may require various planning strategies and policy measures for different cities and countryside [124].

\section{Implications of Resilience Thinking for Sustainability Transitions}

Given the urban-rural dichotomy and identified main challenges, sustainability transitions in China should tackle institutional constraints (e.g., 'hukou' restriction) while synchronizing urban expansion and renewal [125] with agricultural modernization and rural revitalization [126]. Profound changes are required within land use and land management, city management and administration, and regional and urban-rural development. Linking resilience thinking to transition theory, the notions of adaptation and transformation can help URSs with a successful shift to sustainability transitions through the clarification of feedback loops among URSs components $[127,128]$ and the definition of transformative capacity required to shift governance [129].

Here, a framework (Figure 4) is proposed to coordinate "resilience" with "sustainability" for the transition of URSs in response to various policy interventions, such as the 2018 Rural Revitalization [83] and 2014 National New-Type Urbanization Plan [77,98]. Theoretically, policy interventions are initiated to help system mitigate changes and/or navigate changes by stimulating resilience building and sustainability management. Approaches and measures are hence developed to facilitate the mobility of population, resources, knowledge, and innovation while improving associated management and equal distribution among various social groups and urban-rural communities. In terms of resilience building, actions and strategies are undertaken to stimulate absorption, adaptation, and transformation. Scenarios and approaches are generated for sustainability management by defining potential alternative futures, identifying drivers, clarifying solution measures, and assessing uncertainties and effects, given the social, economic, and environmental contexts. To decouple China's economic development from environmental degradation and social imbalance, new indicators and values are required to incorporate economic wealth, human wealth, environmental quality and biodiversity, ecosystem services, social welfare and equity, employment, and others. Associated data and evaluation methods could support system monitoring and feedback into the policy interventions for stable and equitable transitions in a long time. 


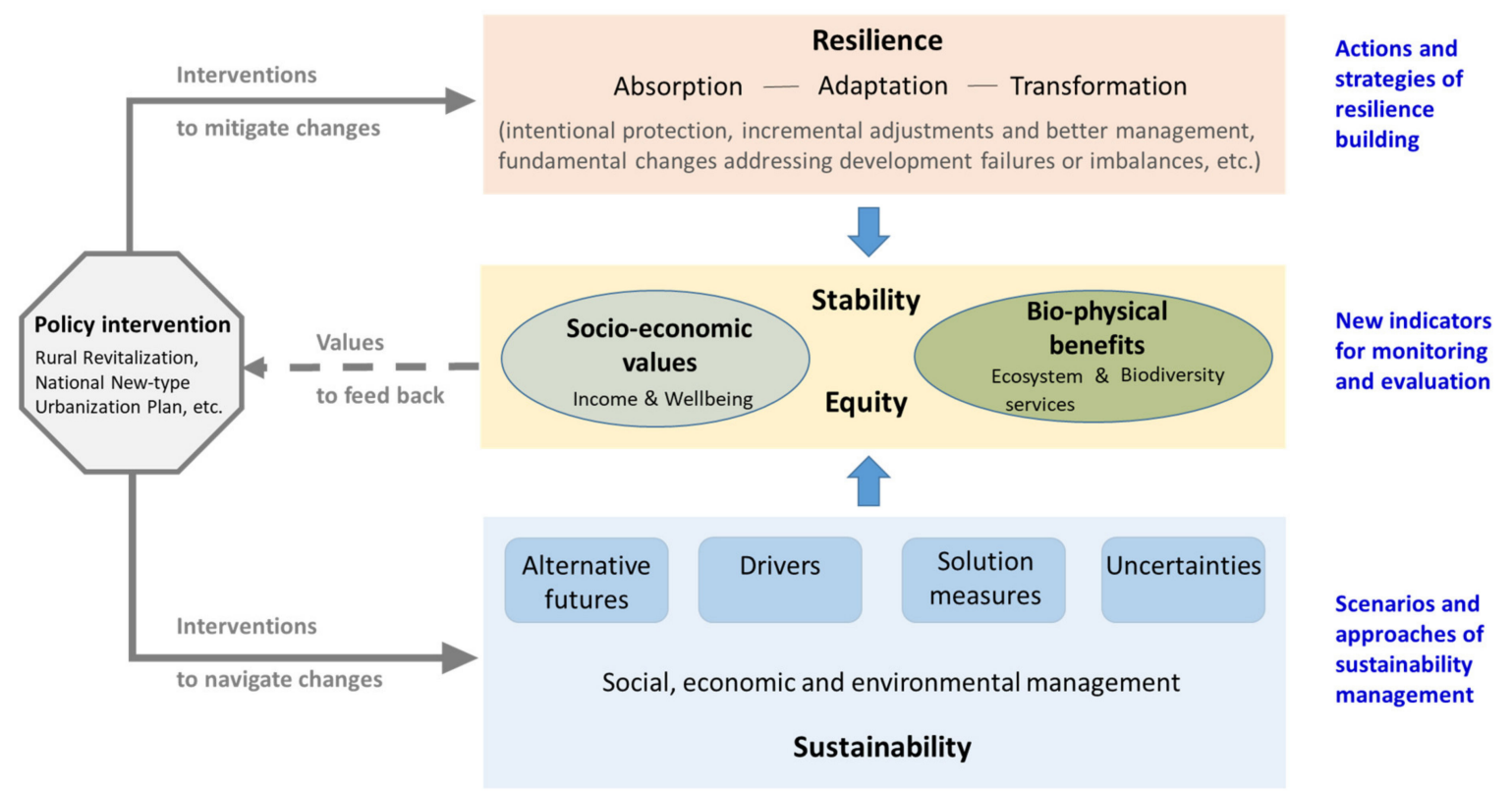

Figure 4. URSs resilience and sustainability framework.

In practice, China is transitioning from pursuing rapid economic growth at any cost to life-quality growth that focuses on sustainability, inclusivity, and efficiency. A series of policy interventions can be designed and implemented accordingly to push and pull URSs to mitigate and navigate changes for efficient land use and land management, adequate city management and administration, and regional and rural-urban equity. For instance, the 'hukou' limits on labour mobility to cities could be removed, to provide rural immigrants equal access to quality services and mainstream urban society [97,119]. The associated regulations that improve labour mobility and incentives might improve the rural infrastructure and economy for revitalization, and ameliorate urban-rural division, urban inequalities, and semi-urbanization. Strict financial regulations could be set up to discourage local governments from over-pursuing land-leasing revenue from land financing and land banking, to place urban finance on a sustainable footing. To increase land-use efficiency, land allocation or land-use zoning could be improved with balanced land acquisition between megacities and small towns. Resource reallocation and provision of stimuli could also prefer the western regions for balanced regional development. Also, land tenure could be secured by registering all rural land, establishing property exchange on local land markets, and ensuring rural migrants' land property rights. Nevertheless, this is a formidable task which is of uncertainties and unprecedented problems, requiring joint efforts of government, industry, researchers, and residents in both urban and rural areas.

To achieve this task, combined knowledge and value systems are vital for dealing with trade-offs and adaptive or transformative management (or stewardship). People with different professions, territorial origin, and cultural roots create different types of knowledge and strive for various forms of values. The synthesis of indigenous knowledge and technocratic knowledge can develop as a collaborative effort through social networks $[127,130,131]$ and refine local practice for "unprecedented solutions" in the Anthropocene [128,132]. Thus, a combined technocratic and bottom-up knowledge production process is vital to capture an inclusive adaptation and equitable urbanization [133]. To facilitate information flows and create a knowledge base for diverse local contexts as well as across different levels and scales, future changes in the scenario development of China's urbanization can be discussed and accessed at different politico-administrative levels, such as the national, provincial, prefecture and city, county, and township levels. It may help identify knowledge gaps, disseminate new approaches and leverage autonomy across different levels, to initiate and smooth a transition process either "from bottom-up" (i.e., from cities or civil societies) or "from top-down" (i.e., from the central government) [134]. Besides, individual and collective engagements should be promoted through 
participatory planning and community development [135] to include the different views and opinions of multiple individuals and their collective imaginations in scenario processes and exercises. This would foster the integration of various forms of knowledge while promoting shared responsibility, as well as prevent conflict among all participants while giving marginalized people an equal opportunity to be included in the planning process. Therefore, the combined knowledge and value systems derived from proactive and conscious individuals and collectives through context-dependent social networks may enable China to grapple with uncertainties and unprecedented problems in its sustainability transitions.

\section{Conclusions}

The study concludes that China has experienced significant institutional changes through four periods since 1949 and witnessed the rural-to-urban movement of land, population, and economic development. As a result of the specific institutional arrangements, urban-rural dichotomy and spatial and social segregation emerged with the controversial 'hukou' control on labour mobility, differentiated land ownership and unequal social welfare, and incomplete property rights. To tackle the institutional constraints while integrating urban and rural development, appropriate policy interventions should be designed and implemented to push and pull the urban-rural systems to mitigate and navigate changes concerning land use and land management, city management and administration, and regional and rural-urban equity. The design and implementation of the policy interventions also require combined knowledge and value systems, engagements of proactive and conscious individuals and collectives, and context-dependent social networks to grapple with uncertainties and unprecedented problems in China's sustainability transitions.

Author Contributions: Q.L. designed and wrote the paper. The author has read and agreed to the published version of the manuscript.

Funding: The APC was funded by the University of Bayreuth and German Research Foundation. The first phase of this research was supported by Horizon 2020, grant number 770141. The paper editing services were funded by the Institute of Water and Soil Conservation, Chinese Academy of Sciences and Ministry of Water Resources, grant number A314021402-2018.

Acknowledgments: The author acknowledges the EU-funded Horizon 2020 project "Transition towards urban sustainability through socially integrative cities in Europe and in China" (TRANS-URBAN-EU-CHINA), which is coordinated by TU Dresden, Germany. This project has received funding from the European Union's Horizon 2020 research and innovation programme under grant agreement No 770141. Technical support provided by the Leibniz Centre for Agricultural Landscape Research (ZALF) was greatly appreciated. The author also thanks Bernhard Müller, Schiappacasse, Jianming Cai, Liou Xie, Stefanie Rößler, and three anonymous referees for their helpful and stimulating comments.

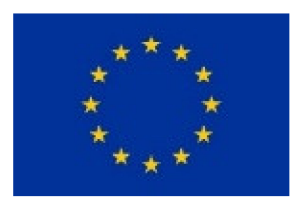

Conflicts of Interest: The author declares no conflict of interest. 


\section{Appendix A}

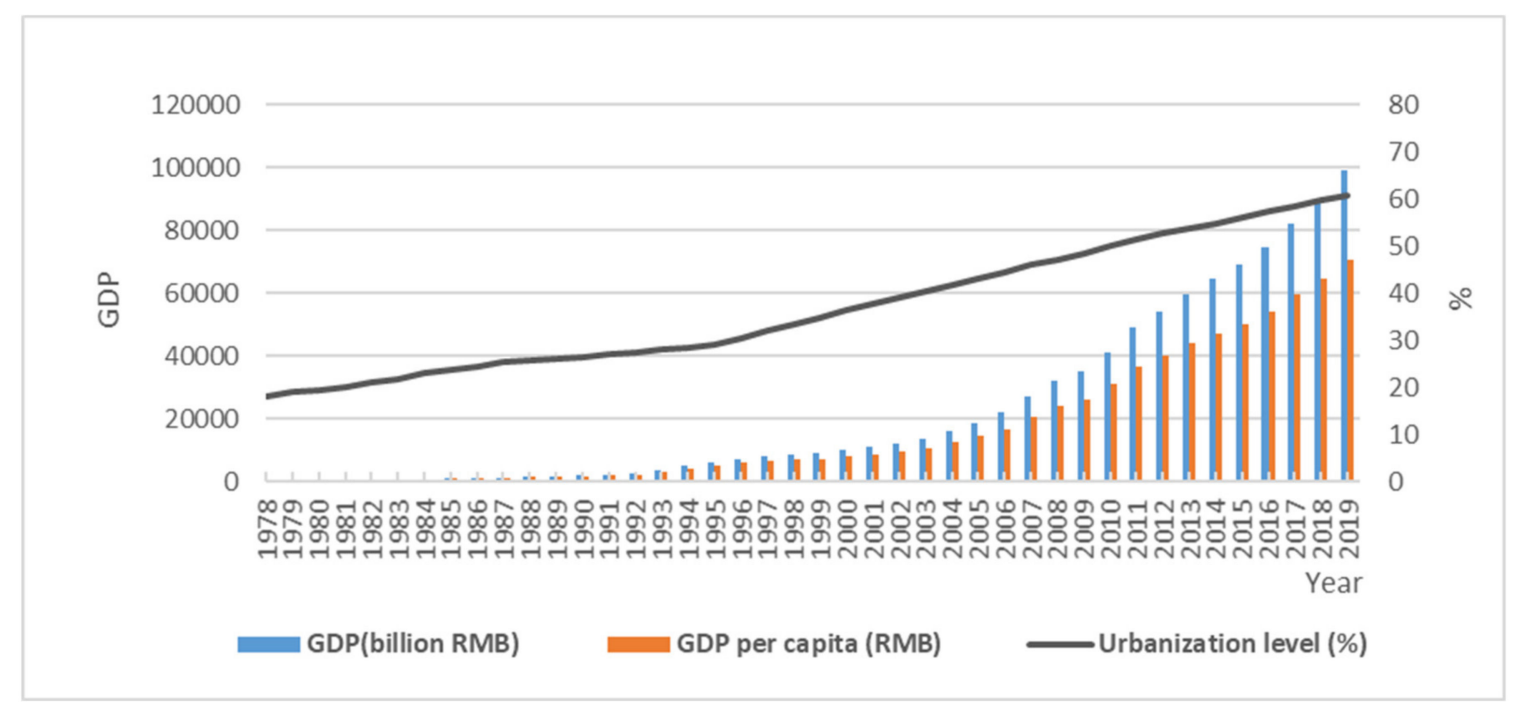

Figure A1. China's urban and economic development from 1978-2019. Source: [4,5].

\section{Appendix B. History Review}

\section{Appendix B.1. Conservative Development (before 1984)}

From 1949 to 1977, China introduced land reform in the countryside and heavy industries in cities to recover its national economy. The 1958 household registration system ('hukou') was introduced to divide the population into agricultural (or rural) and non-agricultural (or urban). This is the start of urban-rural disparity. In the 'hukou' system, everyone must have permanent household registration in only one place. Mobility and motion of the population were under the government's control [63]. Associated capital goods and resources (e.g., land and labour) were allocated internally between state departments, agencies, and enterprises as part of employment benefits [136-139]. Thereafter, urbanization and industrialization processes were compressed whereas agriculture and light industries were prioritized by implementing a series of political change and economic change, i.e., the 'people's communes' and the Great Leap Forward movement in 1958, the Readjustment, Consolidation, Strengthening and Improvement in 1961, and the Great Proletarian Cultural Revolution in $1966[2,3,140]$. For those two decades, China's urbanization processes had been suppressed with the urbanization level decreased from $18.41 \%$ in 1959 to $17.44 \%$ by 1978 [4,141].

In 1978 the Chinese state initiated the socialist market economy and open-door policy. By introducing a market mechanism, the economic structure and urban development strategy were reformed. The Household Responsibility System was introduced to grant farmers user rights of their farmland and working freedom from de-collectivization. An export-oriented economy was initiated by foreign investment in the early 1980s in coastal cities [142]. Foreign companies entered joint ventures with Chinese companies through technology transfer and equipment sale [143]. The economic reform and institutional changes laid the foundations of a new era of development.

\section{Appendix B.2. City-Biased Development (1984 to 2002)}

Policies and reforms were adopted to relocate rural labour and develop urban areas for industrialization and economic growth $[53,144]$. The 'hukou' system reforms started so that rural labour was allowed for off-farm employment in medium and small-sized cities rather than large cities to avoid the over-growth. It was followed by a set of institutional changes in land management, such as the 1988 revised Land Administration Law and the 1990 Provisional Regulation on the Granting and Transferring of the Land Use Rights over the State-Owned Land in Cities and Towns. Land use rights 
were hence enforced for the land assignment, transfer, lease, and mortgage, which reintroduced land values into the property market through sales and taxation. The local governments were enabled by the fiscal contracting system to gain direct income through land transfer and to raise funds through bank loans [145]. The land was hence considered a valuable chip by local governments to attract industrial investments $[2,146]$. A real estate market also emerged in this process, with the urban expansion and regeneration turned to be property-led development $[2,146,147]$.

Since 1992, a series of reforms had been carried to expand the market economy by privatising state-owned enterprises and establishing multiple ownership and supervisory functions. Around 15 million workers were retrenched between 1993 and 1998 [148,149] while rural immigrants were granted access to limited welfare and services in cities [2,60]. In 1998, the development of small cities and towns was proposed as a national strategy to facilitate urbanization [67]. Land leasing revenue could retain to compensate local governments for their reduced revenue. The local governments and developers sequentially took the privilege to capture most of the profits in land leasing, with cities and rural-to-urban immigrants grew quickly $[2,101,102,147]$. Also, 'industrial parks' and 'high-tech parks' were built up to attract foreign direct investments (FDI) into industrial sectors with technology and capital traded for the market access [2,8]. During that period, China's urbanization progressed faster than its economic growth $[98,150]$. In 2001 China joined the World Trade Organization, and a set of policies and institutions (Table 1) were implemented to promote service sector and reinforce intellectual property rights for the further progress of urbanization and economic development.

Appendix B.3. Rapid Urbanization (2002 to 2012)

In 2002 'coordinated urban-rural development' became a national strategy. From then on, the rapid growth of the service sector, governments' stimulus package for fixed-asset investment, and export-oriented manufacturing driven by FDI had been the main drivers of the economic growth, industrialization and urbanization [2,151,152]. Many small and mid-sized non-state-owned businesses expanded in the service sector (e.g., logistics and information and telecommunication) and the domestic market. In that context, the 'hukou' system reformed to encourage rural to urban immigration by eliminating the agricultural and non-agricultural 'hukou', offering permanent residence with a scoring system, and providing permanent residence to farmers who purchase an apartment or have a permanent job contract $[2,74,153,154]$. Also, the agricultural tax was exempted in 2006 after the trials began in 2000 for the rural tax and fee reform, relieving rural burdens and balancing urban-rural development [155].

In 2008, 'integrated urban-rural development' was proposed in the Urban and Rural Planning Law to refine China's economy and urbanization by enhancing domestic consumption [156]. A 4 trillion RMB stimulus package was introduced to stimulate infrastructure and the real estate market. It led to the expansion of construction land and urban agglomeration $[8,69,157]$. City clusters had emerged and been part of China's urbanization strategy to coordinate local administrations concerning population distribution and natural and economic resources management [158]. Each city cluster usually consists of several neighbouring core cities, such as JingJinji urban cluster (Beijing-Tianjin-Tangshan), and seeks institutional innovation to address urban-rural discrepancies and semi-urbanization issues $[56,158,159]$. Semi-urbanization means that a large number of rural immigrants are restricted by the 'hukou' system to get a permanent settlement and equal access to education, healthcare, social welfare and other benefits in the cities $[160,161]$. However, dependence on land revenue and infrastructure investment left China with an excess of industrial overcapacity, unsold residential apartments and large corporate debts, and a growing urban-rural disparity and wealth gap [162,163]. The land demand and competition for commercial and residential uses escalated along with soaring housing prices $[2,147,164]$. Regulations and institutions were hence required to avoid overexpansion of urban boundaries and protect arable land. 
Appendix B.4. Quality Development (2012 to Present)

Given the rapid expansion of investment and the resultant excess of production overcapacity, China transformed into a consumption-driven economy and entered a new phase of urbanization (i.e., from eastern coastal areas to the hinterland, from mega or big cities to small cities and towns, and from city clusters to metropolitan areas) with an emphasis on quality development, innovation and entrepreneurship [165]. The 2015 Supply-side Structural Reform attempted to reduce production capacity (e.g., coal, cement and steel), decrease financial leverage in the corporate sector, de-stock property inventories while stimulating the development of service industries, increasing the supply of public goods and social services, and improving innovation mechanisms and institutional systems for environmental protection, poverty alleviation, equal access and allocation of resources and services, and technological and scientific innovation [163]. The market access for foreign investment was further extended to the manufacturing and service sectors, especially the insurance sector and financial sector, through equal access to government procurement markets and banning the forced technology transfer. By 2017, multinational companies established over 1500 research and development (R\&D) centres in China [166], with the R\&D expenditure tripled as a share of GDP from $0.6 \%$ to $2.1 \%$ between 1997 and 2017 [167].

To stimulate domestic consumption while constraining urban expansion, 'new rural construction' was for the first time equally emphasized with urban redevelopment at the 2012 eighteenth National Congress and in the 2014 National New-Type Urbanization Plan (2014-2020). In 2017, 'rural revitalization' was proposed as a national strategy to improve agricultural production and rural socio-economic and infrastructure development. It was followed by a series of policy supports concerning development strategies and governance, land management and property rights, and agricultural supporting services, such as the Rural Revitalization Strategy (2018-2022) and the 2019 Guiding Opinions on Strengthening and Improving Rural Governance. It expects to continue the rapid economic growth and urbanization from the countryside who has larger development potential than cities. Also, improving management and governance for quality development became a theme in cities. Land use efficiency, population mobility, environmental conservation and green development had been a key principle of the new urban development strategy. Community planning of multiple-stakeholder participation and engagement was supported by the 2015 Opinions on Strengthening Urban-Rural Community Consultation. Institutional arrangements for urban renewal were tested in Guangdong Province [168]. Furthermore, the concept 'metropolis' was introduced into China's urbanization strategy [166], which attempts to control the size of megacities but facilitate urbanization in the surrounding areas, as a new model of city development. 
Appendix C.

Table A1. Urban-Rural Land Transformation, Economic Growth, and Population Shift from 1978 to 2019.

\begin{tabular}{|c|c|c|c|c|c|c|c|c|c|}
\hline Year & $\begin{array}{c}\text { Population } \\
\text { (million) }\end{array}$ & $\begin{array}{c}\text { Urban } \\
\text { Population } \\
\text { (million) }\end{array}$ & $\begin{array}{c}\text { Rural } \\
\text { Population } \\
\text { (million) }\end{array}$ & $\begin{array}{c}\text { Urban } \\
\text { Disposable } \\
\text { Income per } \\
\text { Capita (RMB) }\end{array}$ & $\begin{array}{c}\text { Rural } \\
\text { Disposable } \\
\text { Income per } \\
\text { Capita(RMB) }\end{array}$ & $\begin{array}{c}\text { Urbanization } \\
\text { Level }(\%)\end{array}$ & $\begin{array}{l}\text { Number of } \\
\text { Cities }\end{array}$ & $\begin{array}{l}\text { Urban Area } \\
\left(\mathrm{km}^{2}\right)\end{array}$ & $\begin{array}{c}\text { Area of Built } \\
\text { District }\left(\mathbf{k m}^{2}\right)\end{array}$ \\
\hline 1978 & 962.59 & 172.45 & 790.14 & 343.40 & 133.60 & 17.92 & 193 & - & - \\
\hline 1979 & 975.42 & 184.95 & 790.47 & 405.00 & 160.20 & 18.96 & 216 & - & - \\
\hline 1980 & 987.05 & 191.40 & 795.65 & 477.60 & 191.30 & 19.39 & 223 & - & - \\
\hline 1981 & 1000.72 & 201.71 & 799.01 & 500.40 & 223.40 & 20.16 & 226 & $206,684.00$ & 7438.00 \\
\hline 1982 & 1016.54 & 214.80 & 801.74 & 535.30 & 270.10 & 21.13 & 245 & $335,382.30$ & 7862.00 \\
\hline 1983 & 1030.08 & 222.74 & 807.34 & 564.60 & 309.80 & 21.62 & 281 & $366,315.90$ & 8156.30 \\
\hline 1984 & 1043.57 & 240.17 & 803.40 & 652.10 & 355.30 & 23.01 & 300 & $480,733.30$ & 9249.00 \\
\hline 1985 & 1058.51 & 250.94 & 807.57 & 739.10 & 397.60 & 23.71 & 324 & $458,066.20$ & 9386.20 \\
\hline 1986 & 1075.07 & 263.66 & 811.41 & 900.90 & 423.80 & 24.52 & 353 & $805,834.00$ & 10127.30 \\
\hline 1987 & 1093.00 & 276.74 & 816.26 & 1002.20 & 462.60 & 25.32 & 381 & $898,208.00$ & $10,816.50$ \\
\hline 1988 & 1110.26 & 286.61 & 823.65 & 1180.20 & 544.90 & 25.81 & 434 & $1,052,374.20$ & $12,094.60$ \\
\hline 1989 & 1127.04 & 295.40 & 831.64 & 1375.70 & 601.50 & 26.21 & 450 & $1,137,643.50$ & $12,462.20$ \\
\hline 1990 & 1143.33 & 301.95 & 841.38 & 1510.20 & 686.30 & 26.41 & 467 & $1,165,970.00$ & $12,855.70$ \\
\hline 1991 & 1158.23 & 312.03 & 846.20 & 1700.60 & 708.60 & 26.94 & 479 & $980,685.00$ & $14,011.10$ \\
\hline 1992 & 1171.71 & 321.75 & 849.96 & 2026.60 & 784.00 & 27.46 & 517 & $96,978.00$ & $14,958.70$ \\
\hline 1993 & 1185.17 & 331.73 & 853.44 & 2577.40 & 921.60 & 27.99 & 570 & $1,038,910.00$ & $16,588.30$ \\
\hline 1994 & 1198.50 & 341.69 & 856.81 & 3496.20 & 1221.00 & 28.51 & 622 & $1,104,712.00$ & $17,939.50$ \\
\hline 1995 & 1211.21 & 351.74 & 859.47 & 4283.00 & 1577.70 & 29.04 & 640 & $1,171,698.00$ & $19,264.20$ \\
\hline 1996 & 1223.89 & 373.04 & 850.85 & 4838.90 & 1926.10 & 30.48 & 666 & $987,077.90$ & $20,214.20$ \\
\hline 1997 & 1236.26 & 394.49 & 841.77 & 5160.30 & 2090.10 & 31.91 & 668 & $835,771.80$ & $20,791.30$ \\
\hline 1998 & 1247.61 & 416.08 & 831.53 & 5425.10 & 2162.00 & 33.35 & 668 & $813,585.70$ & $21,379.60$ \\
\hline 1999 & 1257.86 & 437.48 & 820.38 & 5854.00 & 2210.30 & 34.78 & 667 & $812,817.60$ & $21,524.50$ \\
\hline 2000 & 1267.43 & 459.06 & 808.37 & 6255.70 & 2282.10 & 36.22 & 663 & $878,015.00$ & $22,439.30$ \\
\hline 2001 & 1276.27 & 480.64 & 795.63 & 6824.00 & 2406.90 & 37.66 & 662 & $607,644.30$ & $24,026.60$ \\
\hline 2002 & 1284.53 & 502.12 & 782.41 & 7652.40 & 2558.90 & 39.09 & 660 & $467,369.30$ & $25,972.60$ \\
\hline 2003 & 1292.27 & 523.76 & 768.51 & 8405.50 & 2690.30 & 40.53 & 660 & $399,173.20$ & $28,308.00$ \\
\hline 2004 & 1299.88 & 542.83 & 757.05 & 9334.80 & 3026.60 & 41.76 & 661 & $394,672.50$ & $30,406.20$ \\
\hline 2005 & 1307.56 & 562.12 & 745.44 & $10,382.30$ & 3370.20 & 42.99 & 661 & $412,819.10$ & $32,520.70$ \\
\hline 2006 & 1314.48 & 582.88 & 731.60 & $11,619.70$ & 3731.00 & 44.34 & 656 & $166,533.50$ & $33,659.80$ \\
\hline 2007 & 1321.29 & 606.33 & 714.96 & $13,602.50$ & 4327.00 & 45.89 & 655 & $176,065.50$ & $35,469.70$ \\
\hline 2008 & 1328.02 & 624.03 & 703.99 & $15,549.40$ & 4998.80 & 46.99 & 655 & $178,110.30$ & $36,295.30$ \\
\hline
\end{tabular}


Table A1. Cont.

\begin{tabular}{|c|c|c|c|c|c|c|c|c|c|}
\hline Year & $\begin{array}{c}\text { Population } \\
\text { (million) }\end{array}$ & $\begin{array}{c}\text { Urban } \\
\text { Population } \\
\text { (million) }\end{array}$ & $\begin{array}{c}\text { Rural } \\
\text { Population } \\
\text { (million) }\end{array}$ & $\begin{array}{c}\text { Urban } \\
\text { Disposable } \\
\text { Income per } \\
\text { Capita (RMB) }\end{array}$ & $\begin{array}{c}\text { Rural } \\
\text { Disposable } \\
\text { Income per } \\
\text { Capita(RMB) }\end{array}$ & $\begin{array}{c}\text { Urbanization } \\
\text { Level (\%) }\end{array}$ & $\begin{array}{c}\text { Number of } \\
\text { Cities }\end{array}$ & $\begin{array}{c}\text { Urban Area } \\
\left(\mathbf{k m}^{2}\right)\end{array}$ & $\begin{array}{l}\text { Area of Built } \\
\text { District }\left(\mathbf{k m}^{2}\right)\end{array}$ \\
\hline 2009 & 1334.50 & 645.12 & 689.38 & $16,900.50$ & 5435.10 & 48.34 & 654 & $175,463.60$ & $38,107.30$ \\
\hline 2010 & 1340.91 & 669.78 & 671.13 & $18,779.10$ & 6272.40 & 49.95 & 657 & $178,691.70$ & $40,058.00$ \\
\hline 2011 & 1347.35 & 690.79 & 656.56 & $21,426.90$ & 7393.90 & 51.27 & 657 & $183,618.00$ & $43,603.20$ \\
\hline 2012 & 1354.04 & 711.82 & 642.22 & $24,126.70$ & 8389.30 & 52.57 & 657 & $183,039.40$ & $45,565.80$ \\
\hline 2013 & 1360.72 & 731.11 & 629.61 & $26,467.00$ & 9429.60 & 53.73 & 658 & $183,416.10$ & $47,855.30$ \\
\hline 2014 & 1367.82 & 749.16 & 618.66 & $28,843.90$ & $10,488.90$ & 54.77 & 653 & $184,098.60$ & $49,772.60$ \\
\hline 2015 & 1374.62 & 771.16 & 603.46 & $31,194.80$ & $11,421.70$ & 56.10 & 656 & $191,775.50$ & $52,102.30$ \\
\hline 2016 & 1382.71 & 792.98 & 589.73 & $33,616.20$ & $12,363.40$ & 57.35 & 657 & $198,178.60$ & $54,331.50$ \\
\hline 2017 & 1390.08 & 813.47 & 576.61 & $36,396.20$ & $13,432.40$ & 58.52 & 661 & $198,357.20$ & $56,225.40$ \\
\hline 2018 & 1395.38 & 831.37 & 564.01 & $39,250.80$ & $14,617.00$ & 59.58 & 672 & $200,896.50$ & $58,455.70$ \\
\hline 2019 & 1400.05 & 848.43 & 551.62 & $42,359.00$ & $16,021.00$ & 60.60 & - & - & - \\
\hline
\end{tabular}

Appendix D.

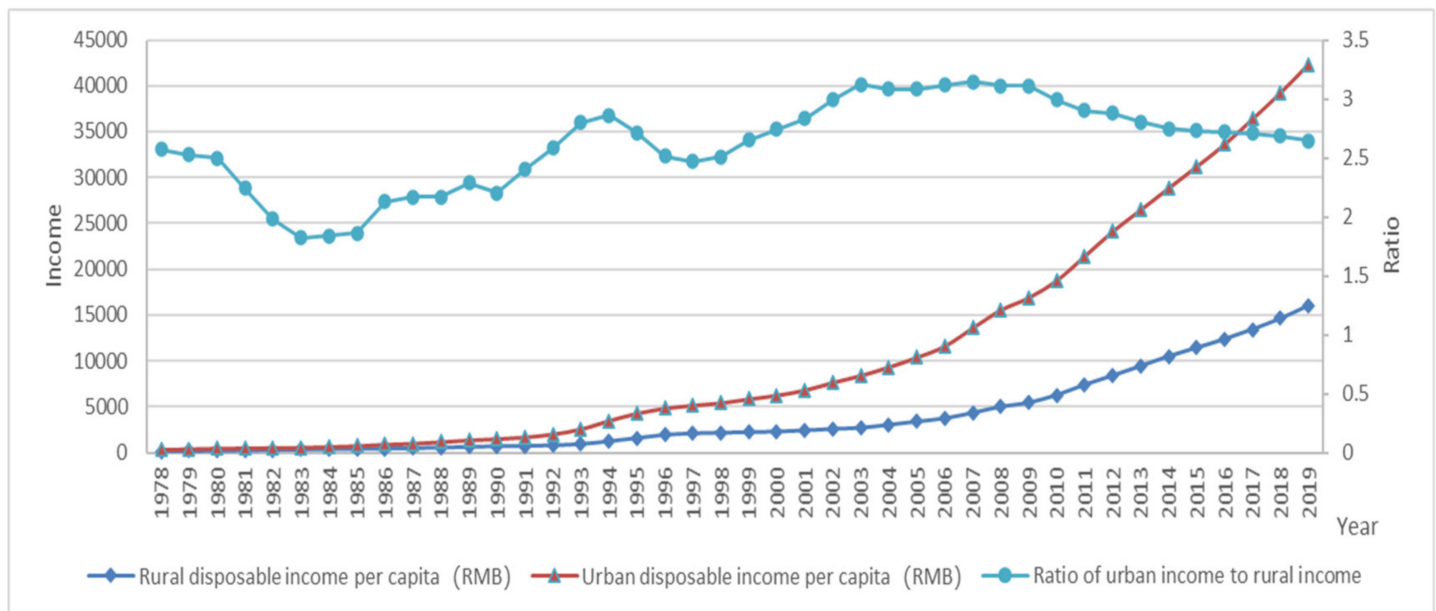

Figure A2. Changes in Urban and Rural Incomes from 1978 to 2019. Source: [4,5]. 


\section{References}

1. Gu, C.; Wu, L.Y.; Ian, C. Progress in research on Chinese urbanization. Front. Arch. Res. 2012, 1, $101-149$. [CrossRef]

2. Yeh, A.G.O.; Yang, F.F.; Wang, J. Economic transition and urban transformation of China: The interplay of the state and the market. Urban Stud. 2015, 52, 2822-2848. [CrossRef]

3. Gu, C.; Hu, L.; Cook, I.G. China's urbanization in 1949-2015, Processes and driving forces. Chin. Geogr. Sci. 2017, 27, 847-859. [CrossRef]

4. National Bureau of Statistics of China. China Population Statistics Yearbook 1990. 1991. Available online: http://data.cnki.net/trade/Yearbook/Single/N2005120414?z=Z001 (accessed on 1 March 2020).

5. National Bureau of Statistics of China. China Statistical Yearbook 2019. 2020. Available online: http: //www.stats.gov.cn/tjsj/ndsj/2019/indexch.htm (accessed on 1 April 2020).

6. Block, F. The roles of the state in the economy. In The Handbook of Economic Sociology; Smelser, N.J., Swedberg, R., Eds.; Princeton University Press: Princeton, NJ, USA, 1994; pp. 691-710.

7. North, D.C. Institutions, Institutional Change and Economic Performance; Cambridge University Press: Cambridge, UK, 1990.

8. Tian, L.; Yao, Z. From state-dominant to bottom-up redevelopment: Can institutional change facilitate urban and rural redevelopment in China. Cities 2018, 76, 72-83. [CrossRef]

9. Holling, C.S. Resilience and stability of ecological systems. Annu. Rev. Ecol. Syst. 1973, 4, 1-23. [CrossRef]

10. Walker, B.; Holling, C.S.; Carpenter, S.R.; Kinzig, A. Resilience, adaptability and transformability in social-ecological systems. Ecol. Soc. 2004, 9, 5. [CrossRef]

11. Folke, C.; Carpenter, S.R.; Walker, B.; Scheffer, M.; Chapin, T.; Rockström, J. Resilience thinking: Integrating resilience, adaptability and transformability. Ecol. Soc. 2010, 15, 20. Available online: http://www. ecologyandsociety.org/vol15/iss4/art20/ (accessed on 1 April 2020). [CrossRef]

12. Evans, N.J.; Forney, D.S.; Guido-DiBrito, F. Student Development in College: Theory, Research, and Practice; Jossey-Bass: San Francisco, CA, USA, 2010.

13. Van den Bergh, J.C.J.M.; Truffer, B.; Kallis, G. Environmental innovation and societal transitions: Introduction and overview. Environ. Innov. Soc. Transit. 2011, 1, 1-23. [CrossRef]

14. Folke, C.; Carpenter, S.; Elmqvist, T.; Gunderson, L.; Holling, C.S.; Walker, B. Resilience and sustainable development: Building adaptive capacity in a world of transformations. Ambio 2002, 31, 437-440. [CrossRef]

15. Béné, C.; Wood, R.G.; Newsham, A.; Davies, M. Resilience: New Utopia or New Tyranny? Reflection about the Potentials and Limits of the Concept of Resilience in Relation to Vulnerability Reduction Programmes; IDS Working Papers; Institute of Development Studies Publications: London, UK, 2012; pp. 1-61.

16. Jeans, H.; Castillo, G.E.; Thomas, S. The Future is a Choice: Absorb, Adapt, Transform Resilience Capacities; Oxfam GB for Oxfam International: Oxford, UK, 2017.

17. Lumbroso, D.M.; Suckall, N.R.; Nicholls, R.J.; White, K.D. Enhancing resilience to coastal flooding from severe storms in the USA: International lessons. Nat. Hazards Earth Syst. Sci. 2017, 17, 1357-1373. [CrossRef]

18. Li, Q.; Zander, P. Resilience building of rural livelihoods in PES programmes: A case study in China's Loess Hills. Ambio 2020, 49, 962-985. [CrossRef] [PubMed]

19. Li, Q.; Amjath-Babu, T.S.; Zander, P. Role of capitals and capabilities in ensuring economic resilience of land conservation efforts: A case study of the grain for green project in China's Loess Hills. Ecol. Indic. 2016, 71, 636-644. [CrossRef]

20. Li, Q.; Amjath-Babu, T.S.; Sieber, S.; Zander, P. Assessing divergent consequences of payments for ecosystem services on rural livelihoods: A case-study in China's Loess Hills. Land Degrad. Dev. 2018, 29, 3549-3570. [CrossRef]

21. Geels, F.W. The multi-level perspective on sustainability transitions: Responses to seven criticisms. Environ. Innov. Soc. Transit. 2011, 1, 24-40. [CrossRef]

22. Twomey, P.; Gaziulusoy, L. Review of System Innovation and Transitions Theories Concepts and Frameworks for Understanding and Enabling Transitions to a Low Carbon Built Environment; Working Paper; University of Melbourne Publications: Parkville, VIC, Australia, 2014. [CrossRef]

23. Robinson, G.M.; Carson, D.A. Resilient communities: Transitions, pathways and resourcefulness. Geogr. J. 2016, 182, 114-122. [CrossRef] 
24. Meadows, D.H. Leverage Points: Places to Intervene in a System; The Sustainability Institute: Hartland, VT, USA, 1999.

25. Lewis, W.A. Economic development with unlimited supplies of labor. Manch. Sch. 1954, 22, $139-191$. [CrossRef]

26. Folke, C.; Colding, J.; Berkes, F. Synthesis: Building Resilience For adaptive Capacity in Social-Ecological Systems. In Navigating Social-Ecological Systems: Building Resilience for Complexity and Change; Cambridge University Press: Cambridge, UK, 2003; pp. 352-387.

27. Olsson, P.; Folke, C.; Berkes, F. Adaptive co-management for building social-ecological resilience. Environ. Manag. 2004, 34, 75-90. [CrossRef]

28. Cumming, G.S.; von Cramon-Taubadel, S. Linking economic growth pathways and environmental sustainability by understanding development as alternate social-ecological regimes. Proc. Natl. Acad. Sci. USA 2018, 115, 9533-9538. [CrossRef]

29. Cumming, G.S.; Buerkert, A.; Hoffmann, E.M.; Schlecht, E.; von Cramon-Taubadel, S.; Tscharntke, T. Implications of agricultural transitions and urbanization for ecosystem services. Nature 2014, 515, 50-57. [CrossRef]

30. Wilson, S.; Pearson, L.J.; Kashima, Y.; Lusher, D.; Pearson, C. Separating adaptive maintenance (resilience) and transformative capacity of social-ecological systems. Ecol. Soc. 2013, 18, 22. [CrossRef]

31. Lonsdale, K.; Pringle, P.; Turner, B. Transformative Adaptation What It Is, Why it Matters and What Is Needed; UK Climate Impacts Programme, University of Oxford: Oxford, UK, 2015.

32. Park, S.E.; Marshall, N.A.; Jakku, E.; Dowd, A.M.; Howden, S.M.; Mendham, E.; Fleming, A. Informing adaptation responses to climate change through theories of transformation. Glob. Environ. Chang. 2012, 22, 115-126. [CrossRef]

33. Kates, R.W.; Travis, W.R.; Wilbanks, T.J. Transformational adaptation when incremental adaptations to climate change are insufficient. Proc. Natl. Acad. Sci. USA 2012, 109, 7156-7161. [CrossRef] [PubMed]

34. Smits, R. Innovation studies in the 21st century: Questions from a user's perspective. Technol. Forecast. Soc. Chang. 2002, 69, 861-883. [CrossRef]

35. Hermans, F. The potential contribution of transition theory to the analysis of bioclusters and their role in the transition to a bioeconomy. Biofuels Bioprod. Biorefin. 2018, 12, 265-276. [CrossRef]

36. Freeman, C.; Perez, C. Structural crisis of adjustment, business cycles and investment behaviour. In Technical Change and Economic Theory; Dosi, G., Freeman, C., Nelson, R., Silverberg, G., Soete, L., Eds.; Pinter: London, UK, 1988.

37. Cumming, G.S.; Barnes, G.; Perz, S.; Schmink, M.; Sieving, K.E.; Southworth, J.; Binford, M.; Holt, R.D.; Stickler, C.; van Holt, T. An Exploratory Framework for the Empirical Measurement of Resilience. Ecosystems 2005, 8, 975-987. [CrossRef]

38. Cumming, G.S.; Collier, J. Change and identity in complex systems. Ecol. Soc. 2005, 10, 29. [CrossRef]

39. Wiggins, D. Identity and Spatio-Temporal Continuity; Oxford University Press: Oxford, UK, 1967.

40. Rotarangi, S.J.; Stephenson, J. Resilience pivots: Stability and identity in a social-ecological-cultural system. Ecol. Soc. 2014, 19, 28. [CrossRef]

41. Ingalls, M.; Stedman, R. Engaging with human identity in social-ecological systems: A dialectical approach. Hum. Ecol. Rev. 2017, 23, 45-63. [CrossRef]

42. Stokols, D.; Shumaker, S.A. People in places: A transactional view of settings. In Cognition, Social Behavior, and the Environment; Harvey, J.H., Ed.; Lawrence Erlbaum: Hillsdale, NJ, USA, 1981; pp. 441-488.

43. Proshansky, H.M. The city and self-identity. Environ. Behav. 1978, 10, 147-169. [CrossRef]

44. Lyon, C. Place systems and social resilience: A framework for understanding place in social adaptation, resilience, and transformation. Soc. Nat. Resour. 2014, 27, 1009-1023. [CrossRef]

45. Jones, N.A.; Shaw, S.; Ross, H.; Witt, K.; Pinner, B. The study of human values in understanding and managing social-ecological systems. Ecol. Soc. 2016, 21, 15. [CrossRef]

46. Brown, K. Resilience, Development and Global Change; Routledge: London, UK, 2015.

47. Masterson, V.A.; Vetter, S.; Chaigneau, T.; Daw, T.M.; Selomane, O.; Hamann, M.; Wong, G.Y.; Mellegard, V.; Cocks, M.; Tengö, M. Revisiting the relationships between human well-being and ecosystems in dynamic social-ecological systems: Implications for stewardship and development. Glob. Sustain. 2019, 2, 1-14. [CrossRef] 
48. De Paoli, H.; van der Heide, T.; van den Berg, A.; Silliman, B.R.; Herman, P.M.J.; van de Koppel, J. Behavioral self-organization underlies the resilience of a coastal ecosystem. Proc. Natl. Acad. Sci. USA 2017, 114, 8035-8040. [CrossRef] [PubMed]

49. Rotarangi, S.; Russell, D. Social-ecological resilience thinking: Can indigenous culture guide environmental management? J. R. Soc. N. Z. 2009, 39, 209-213. [CrossRef]

50. Wieczorek, A.; Hekkert, M. System Instruments for Systemic Innovation Problems: A Framework for Policy Makers and Innovation Scholars; Innovation Studies Utrecht Working Paper No. 11.08; Universiteit Utrecht: Utrecht, The Netherlands, 2011.

51. Bergek, A.; Jacobsson, S.; Carlsson, B.; Lindmark, S.; Rickne, A. Analyzing the functional dynamics of technological innovation systems: A scheme of analysis. Res. Policy 2008, 37, 407-429. [CrossRef]

52. Scheffer, M.; Carpenter, S.R.; Lenton, T.M.; Bascompte, J.; Brock, W.; Dakos, V.; van de Koppel, J.; van de Leemput, I.A.; Levin, S.A.; van Nes, E.H.; et al. Anticipating critical transitions. Science 2012, 338, 344-348. [CrossRef] [PubMed]

53. Fei, X. The road to China's urban and rural development. China City Plan. Rev. 1994, 10, 2-11.

54. Chan, K. The household registration system and migrant labor in China: Notes on a debate. Popul. Dev. Rev. 2010, 36, 357-364. [CrossRef]

55. Bosker, M.; Brakman, S.; Garretsen, H.; Schramm, M. Relaxing Hukou: Increased labor mobility and China's economic geography. J. Urban Stud. 2012, 72, 252-266. [CrossRef]

56. Wu, Q.; Zhang, X.; Xu, Y.; Li, T. Dualities of semi-urbanization villages in social-spatial transition: A case study of Zhoucun village in suburban Nanjing, China. J. Rural Stud. 2016, 47, 657-664. [CrossRef]

57. Bennett, M.T.; Mehta, A.; Xu, J. Incomplete property rights, exposure to markets and the provision of environmental services in China. China Econ. Rev. 2011, 22, 485-498. [CrossRef]

58. Brandt, L.; Turner, M.; Scott, R. Local Government Behaviour and Property Rights Formation in Rural China; Working Paper; Department of Economics, University of Toronto: Toronto, ON, Canada, 2002.

59. Lu, Y. Rural Development in China: The Rise of Innovative Institutions and Markets (Volume 3); Enrich Professional Publishing: Hong Kong, China, 2015.

60. Fabre, G.; Grumbach, S. The World upside down, China's RD and innovation strategy. In Intervention au Séminaire "BRICs" du 14 Novembre 2011, Sur le Thème: La Stratégie de Recherche; FMSH-WP-2012-07; halshs-00686389; Fondation Maison des Sciences de l'Homme: Paris, France, 2012.

61. Gu, C.; Kesteloot, C.; Cook, I.G. The rising Chinese urbanization: A multi-layered perspective. Urban Stud. 2015, 52, 2564-2580. [CrossRef]

62. Zhao, C. Socio-Spatial Transformation in Mao's China: Settlement Planning and Dwelling Architecture Revisited (1950s-1970s); University of Leuven: Leuven, Belgium, 2007.

63. Chan, K. Cities with Invisible Walls: Reinterpreting Urbanization in Post-1949 China; Oxford University Press: Hong Kong, China, 1994.

64. National People's Congress. Law of the People's Republic of China on Chinese-Foreign Equity Joint Ventures. Adopted at the Second Session of the Fifth National People's Congress on 1 July 1979. Available online: http://english.mofcom.gov.cn/article/policyrelease/Businessregulations/201303/20130300045777.shtml (accessed on 1 January 2020).

65. State Council. Notice on the question of rural migrant population. Bull. State Council 1984, 26, 919-920. (In Chinese)

66. Garnaut, R.; Song, L.; Yao, Y.; Wang, X. Development of the Role of Private Enterprise in China. In Private Enterprise in China; ANU Press: Canberra, ACT, Australia, 2012.

67. Zheng, Y.; Tong, S.Y. China's Evolving Industrial Policies and Economic Restructuring; Routledge: Abingdon, UK, 2014.

68. Lin, G.C.S.; Ho, S.P.S. The state, land system, and land development processes in contemporary China. Ann. Assoc. Am. Geogr. 2005, 95, 411-436. [CrossRef]

69. Tian, L. Land Values, Property Rights and Urban Development: Betterment and Compensation under the Land Use Rights of China; Edward Elgar Publishing: Cheltenham, UK, 2014.

70. State Council. Several Opinions of the CPC Central Committee and the State Council on Promoting the Development of Small Towns; Central Committee of the Chinese Communist Party and State Council: Beijing, China, 2000. Available online: http://www.gov.cn/gongbao/content/2000/content_60314.htm (accessed on 1 April 2020). 
71. Ye, X.; Christiansen, F. China's Urban-Rural Integration Policies. J. Curr. Chin. Aff. 2009, 38, 117-143. [CrossRef]

72. Liang, W.; Lu, M.; Zhang, H. Housing prices raise wages: Estimating the unexpected effects of land supply regulation in China. J. Hous. Econ. 2016, 33, 70-81. [CrossRef]

73. Rithmire, M. Land institutions and Chinese political economy: Institutional complementaries and macroeconomics management. Politics Soc. 2017, 45, 123-153. [CrossRef]

74. Deininger, K.; Jin, S.; Liu, S.; Shao, T.; Xia, F. Property rights reform to support China's rural-urban integration: Village-level evidence from the Chengdu experiment. Oxf. Bull. Econ. Stat. 2019. [CrossRef]

75. Economic Information Daily. The Ministry of Land and Resources to Clean Up the Link of the Increase in Land Used for Urban Construction with the Decrease in Land Used for Rural Construction. 2011. Available online: http://www.mlr.gov.cn/xwdt/jrxw/201102/t20110214816140.html (accessed on 31 December 2019).

76. Lu, X. Social Structure and Social Stratification in Contemporary China; Routledge: New York, NY, USA, 2020.

77. State Council. National New-Type Urbanization Plan (2014-2020); Central Committee of the Chinese Communist Party and State Council: Beijing, China, 2014. Available online: http://www.gov.cn/zhengce/2014-03/16/ content_2640075.htm (accessed on 15 March 2017).

78. Xin Hua Net. China's 'supply-side structural reform' to boost new economy. China Daily. 31 December 2015. Available online: http://www.chinadaily.com.cn/business/2015-12/31/content_22885118.htm (accessed on 6 January 2018).

79. State Council. Integrated Reform Plan for Promoting Ecological Progress; Central Committee of the Chinese Communist Party and State Council: Beijing, China, 2015. Available online: http://www.gov.cn/guowuyuan/ 2015-09/21/content_2936327.htm (accessed on 15 March 2017).

80. State Council. Several Opinions of the CPC Central Committee and the State Council on Strengthen Urban and Rural Community Consultations; Central Committee of the Chinese Communist Party and State Council: Beijing, China, 2015. Available online: http://www.gov.cn/zhengce/2015-07/22/content_2900883.htm (accessed on 15 March 2017).

81. China Daily. Lucid Waters and Lush Mountains are Invaluable Assets. 2017. Available online: http: //www.chinadaily.com.cn/china/19thcpcnationalcongress/2017-10/09/content_33032118.htm (accessed on 6 January 2018).

82. State Council. Notice of the State Council on Several Measures for Expanding Opening up and Vigorously Using Foreign Capital, Central No. 5 Document; Central Committee of the Chinese Communist Party and State Council: Beijing, China, 2017. Available online: https://www.pkulaw.com/en_law/288956.html (accessed on 6 January 2018).

83. State Council. Rural Vitalization Strategy (2018-2022); Central Committee of the Chinese Communist Party and State Council: Beijing, China, 2018. Available online: http://www.gov.cn/xinwen/2018-09/26/content_ 5325534.htm (accessed on 1 April 2020).

84. China Daily. Residency Shift Part of Plan to Boost Urban Base. 2019. Available online: http://www.chinadaily. com.cn/a/201904/09/WS5cab92b7a3104842260b5049.html (accessed on 1 April 2020).

85. State Council. Guiding Opinions on Strengthening and Improving Rural Governance; Central Committee of the Chinese Communist Party and State Council: Beijing, China, 2019. Available online: http://www.gov.cn/ zhengce/2019-06/23/content_5402625.htm (accessed on 1 January 2020).

86. State Council. Several opinions of the CPC central committee and the state council on developing a modern metropolitan area; Central Committee of the Chinese Communist Party and State Council: Beijing, China, 2019. Available online: http://www.ndrc.gov.cn/zcfb/zcfbtz/201902/t20190221_928319.html (accessed on 1 January 2020).

87. Xin Hua Net. Foreign investment law takes effect in China. 2020. Available online: www.xinhuanet.com/ english/2020-01/01/c_138670986.htm (accessed on 1 April 2020).

88. Ma, R.; Gu, C.; Pu, Y.; Ma, X. Mining the urban sprawl pattern: A case study on Sunan, China. Sensors 2008, 8, 6371-6395. [CrossRef]

89. National Bureau of Statistics of China. China Statistical Yearbook 2018. 2019. Available online: http: //www.stats.gov.cn/tjjj/ndsj/2018/indexch.htm (accessed on 31 December 2019).

90. Palmer, I.; Berrisford, S. Final Report on Land-Based Financing for Urban Infrastructure in Sub-Saharan African Cities; Retrieved 16 September 2017; African Centre for Cities: Cape Town, South Africa, 2015. Available online: https://assets.publishing.service.gov.uk/media/57a08978ed915d622c000227/61319C_FullDFID-Report_Web.1.1.pdf (accessed on 1 April 2020). 
91. Guo, S.; Shi, Y. Infrastructure investment in China: A model of local government choice under land financing. J. Asian Econ. 2018, 56, 24-35. [CrossRef]

92. Wu, Q.; Li, Y.; Yan, S. The incentives of China's urban land finance. Land Use Policy 2015, 42, 432-442. [CrossRef]

93. Zheng, H.; Wang, X.; Cao, S. The land finance model jeopardizes China's sustainable development. Habitat Int. 2014, 44, 130-136. [CrossRef]

94. Zhong, T.; Zhang, X.; Huang, X.; Liu, F. Blessing or curse? Impact of land finance on rural public infrastructure development. Land Use Policy 2019, 85, 130-141. [CrossRef]

95. Ong, L. State-led urbanization in China: Skyscrapers, land revenue and 'concentrated villages'. China $Q$. 2014, 217, 162-179. [CrossRef]

96. Fan, C.C. China on the Move: Migration, the State, and the Household; Routledge: Abingdon, UK, 2008.

97. Wu, F.; Logan, J. Do rural migrants 'float' in urban China? Neighbouring and neighbourhood sentiment in Beijing. Urban Stud. 2016, 53, 2973-2990. [CrossRef]

98. Wang, X.; Hui, E.C.; Choguill, C.; Jia, S. The new urbanization policy in China: Which way forward? Habitat Int. 2015, 47, 279-284. [CrossRef]

99. Yu, L. Analysis of technology support system for the new urbanization. Sci. Technol. Prog. Policy 2014, 31, $46-49$.

100. Gu, C.; Guan, W.; Liu, H. Chinese urbanization 2050, SD modeling and process simulation. Sci. China Earth Sci. 2017, 60, 1067-1082. [CrossRef]

101. Lin, G.C.S. Scaling-up regional development in globalizing China: Local capital accumulation, land-centered politics, and reproduction of space. Reg. Stud. 2009, 43, 429-447. [CrossRef]

102. Lin, G.C.S.; Yi, F. Urbanization of capital or capitalization on urban land? Land development and municipal finance in urbanizing China. Urban Geogr. 2011, 32, 50-79. [CrossRef]

103. Zhang, Q.; Wallace, J.; Deng, X.; Seto, K.C. Central versus local states: Which matters more in affecting China's urban growth? Land Use Policy 2014, 38, 487-496. [CrossRef]

104. Perlman, J. Favela: Four Decades of Living on the Edge in Rio de Janeiro; Oxford University Press: Oxford, UK, 2010.

105. Webster, C.; Wu, F.; Zhang, F.; Sarkar, C. Informality, property rights, and poverty in China's "favelas". World Dev. 2016, 78, 461-476. [CrossRef]

106. World Bank. China's Rapid Urbanization: Benefits, Challenges \& Strategies. 2008. Available online: https:// www.worldbank.org/en/news/feature/2008/06/19/chinas-rapid-urbanization-benefits-challenges-strategies (accessed on 31 August 2019).

107. Cohen, T.; Cavoli, C. Automated vehicles: Exploring possible consequences of government (non) intervention for congestion and accessibility. Transp. Rev. 2019, 39, 129-151. [CrossRef]

108. Creutzig, F.; Franzen, M.; Moeckel, R.; Heinrichs, D.; Nagel, K.; Nieland, S.; Weisz, H. Leveraging digitalization for sustainability in urban transport. Glob. Sustain. 2019, 2, e14. [CrossRef]

109. Wadud, Z.; MacKenzie, D.; Leiby, P. Help or hindrance? The travel, energy and carbon impacts of highly automated vehicles. Transp. Res. Part A Policy Pract. 2016, 86, 1-18. [CrossRef]

110. Güneralp, B.; Perlstein, A.S.; Seto, K.C. Balancing urban growth and ecological conservation: A challenge for planning and governance in China. Ambio 2015, 44, 532-543. [CrossRef]

111. Jiang, L.; Deng, X.; Seto, K.C. The impact of urban expansion on agricultural land use intensity in China. Land Use Policy 2013, 35, 33-39. [CrossRef]

112. Su, W.; Sun, R. Carbon emissions from urbanization in typical agglomerations of China: Spatial patterns and drivers. Acta Ecol. Sin. 2018, 38, 1-9. (In Chinese)

113. Ren, H.; Liu, G. A Research on the different impacts of urbanization stages on carbon emissions: Based on the panel data of provinces. Econ. Surv. 2014, 31, 1-7.

114. Seto, K.C. What Should We Understand about Urbanization in China? Yale School of Management: New Haven, CT, USA, 2013.

115. Han, L.; Guo, J.; Liu, Z. International comparison and inspiration on urbanization: Understanding of the present stage of urbanization in China. Urban Dev. Stud. 2014, 21, 1-27. (In Chinese)

116. Yang, Z.; Dunford, M. City shrinkage in China: Scalar processes of urban and hukou population losses. Reg. Stud. 2018, 52, 1111-1121. [CrossRef]

117. Xiao, Y.; Song, Y.; Wu, X. How Far Has China's Urbanization Gone? Sutainability 2018, 1121, 2953. [CrossRef] 
118. Xu, D.; Deng, X.; Guo, S.; Liu, S. Labor migration and farmland abandonment in rural China: Empirical results and policy implications. J. Environ. Manag. 2019, 232, 738-750. [CrossRef] [PubMed]

119. Fan, C.C. The elite, the natives and the outsiders: Migration and labor market segmentation in urban China. Ann. Assoc. Am. Geogr. 2002, 92, 103-124. [CrossRef]

120. Xu, Y.; Tang, B.S.; Chan, E.H. State-led land requisition and transformation of rural villages in transitional China. Habitat Int. 2011, 35, 57-65. [CrossRef]

121. Chung, H. Rural transformation and the persistence of rurality in China. Eurasian Geogr. Econ. 2013, 54, 594-610. [CrossRef]

122. Wu, Y.; Jiang, W.; Luo, J.; Zhang, X.; Skitmore, M. How Can Chinese Farmers' Property Income Be Improved? China World Econ. 2019, 27, 107-126. [CrossRef]

123. National Development and Reform Commission. Notice on Carrying out the Work of the National Urban-Rural Integration Development Pilot Zone. 2019. Available online: https://www.ndrc.gov.cn/xxgk/ zcfb/tz/201912/t20191227_1216773.html (accessed on 1 April 2020).

124. Qiao, L.; Liu, Y. China's rural revitalization strategy and rural homestead system reform in the new period. Geogr. Res. 2019, 38, 655-666. [CrossRef]

125. Qian, J.; Peng, Y.; Luo, C.; Wu, C.; Du, Q. Urban land expansion and sustainable land use policy in Shenzhen: A case study of China's rapid urbanization. Sustainability 2016, 8, 16. [CrossRef]

126. Wang, H.; Zhou, Y. The necessary way for the development of China's rural areas in the new era-rural revitalization strategy. Open J. Soc. Sci. 2018, 6, 97-106. [CrossRef]

127. Clark, W.C.; Kerkhoff, L.; van Lebel, L.; Gallopin, G.C. Crafting usable knowledge for sustainable development. Proc. Natl. Acad. Sci. USA 2016, 113, 4570-4578. [CrossRef] [PubMed]

128. Pereira, L.; Sitas, N.; Raveral, F.; Jimenez-Aceituno, A.; Merrie, A. Building capacities for transformative change towards sustainability: Imagination in intergovernmental science-policy scenario processes. Elem. Sci. Anthr. 2019, 7, 35. [CrossRef]

129. Olsson, P.; Bodin, Ö.; Folke, C. Building transformative capacity for ecosystem stewardship in social-ecological systems. In Adaptive Capacity and Environmental Governance; Chapter 13; Armitage, D., Plummer, R., Eds.; Springer-Verlag: Berlin/Heidelberg, Germany, 2010.

130. Dieleman, H.; Huisingh, D. Games by which to learn and teach about sustainable development: Exploring the relevance of games and experiential learning for sustainability. J. Clean. Prod. 2006, 14, 837-847. [CrossRef]

131. Moore, M.L.; Tjornbo, O.; Enfors, E.; Knapp, C.; Hodbod, J.; Baggio, J.A.; Norström, A.; Olsson, P.; Biggs, D. Studying the complexity of change: Toward an analytical framework for understanding deliberate social-ecological transformations. Ecol. Soc. 2014, 19, 54. [CrossRef]

132. Milkoreit, M. The promise of climate fiction-Imagination, storytelling and the politics of the future. In Reimagining Climate Change; Wapner, P., Elver, H., Eds.; Routledge: Oxford, UK, 2016; pp. 171-191. [CrossRef]

133. Ziervogel, G.; Pelling, M.; Cartwright, A.; Chu, E.; Deshpande, T.; Harris, L.; Hyams, K.; Kaunda, J.; Klaus, B.; Michael, K.; et al. Inserting rights and justice into urban resilience: A focus on everyday risk. Environ. Urban. 2017, 29, 123-138. [CrossRef]

134. Müller, B.; Li, Q.; Schiappacasse, P.; Cai, J. D 6.6 Workshop Report on "Theoretical Aspects of Transition Towards Urban Sustainability and the Role of Socially Integrative Cities". 2019. Available online: https: //www.researchgate.net/publication/332571315 (accessed on 1 January 2020).

135. McTague, C.; Jakubowski, S. Marching to the beat of a silent drum: Wasted consensus-building and failed neighborhood participatory planning. Appl. Geogr. 2013, 44, 182-191. [CrossRef]

136. Gao, Z. What is the best economic setup for China? Soc. Sci. China 1980, 1, 7-17.

137. Ma, L.J.C. Anti-urbanism in China. Proc. Assoc. Am. Geogr. 1976, 8, 114-118.

138. Kirkby, R.J.R. Urbanization in China: Town and Country in a Developing Economy, 1949-2000 AD; Billing \& Sons Limited: Worcester, MA, USA, 1985.

139. Yeh, A.G.O. Dual land markets and internal spatial structure of Chinese cities. In Restructuring the Chinese City: Changing Society, Economy and Space; Ma, L.J.C., Wu, F., Eds.; Routledge: London, UK, 2005; pp. 59-79.

140. Cook, I.G.; Murray, G. China's Third Revolution: Tensions in the Transition to Post-Communism; Curzon: London, UK, 2001. 
141. Han, S.S. Controlled Urbanization in China, 1949-1989. Ph.D. Thesis, Simon Fraser University, Burnaby, BC, Canada, 1994. Available online: http://summit.sfu.ca/system/files/iritems1/6538/b16962813.pdf (accessed on 1 April 2020).

142. Wu, W.; Gaubatz, P. The Chinese City; Routledge: Abingdon, NY, USA, 2013.

143. Springut, M.; Schlaikjer, S.; Chen, D. China's Program for Science and Technology Modernization: Implications for American Competitiveness. Prepared for the US-China Economic and Security Review Commission; CENTRA Technology, Inc.: Arlington, VA, USA, 2011.

144. Chang, S. Modernization and China's urban development. Ann. Assoc. Am. Geogr. 1981, 71, $202-219$. [CrossRef]

145. Oi, J.C. Fiscal reform and the economic foundations of local state corporatism in China. World Politics 1992, 45, 99-126. [CrossRef]

146. Yeh, A.G.O.; Wu, F. The new land development process and urban development in Chinese cities. Int. J. Urban Reg. Res. 1996, 20, 330-353. [CrossRef]

147. Wu, F.; Xu, J.; Yeh, A.G.O. Urban Development in Post-Reform China: State, Market, and Space; Routledge: Abingdon, NY, USA, 2007.

148. Cai, Y. The resistance of Chinese laid-off workers in the reform period. China Q. 2002, 170, 327-344. [CrossRef]

149. Solinger, D. Why we cannot count the 'unemployed'. China Q. 2001, 167, 671-688. [CrossRef]

150. Chen, M.; Liu, W.; Tao, X. Evolution and assessment on China's urbanization 1960-2010, Under-urbanization or over-urbanization? Habitat Int. 2013, 38, 25-33. [CrossRef]

151. Logan, J. Urban China in Transition; Blackwell: Oxford, UK; Malden, MA, USA, 2007.

152. Gaubatz, P. China's urban transformation: Patterns and processes of morphological change in Beijing, Shanghai and Guangzhou. Urban Stud. 1999, 36, 1495-1521. [CrossRef]

153. Chan, K.; Buckingham, W. Is China abolishing the hukou system? China Q. 2008, 195, 592-606. [CrossRef]

154. Chan, K. Crossing the 50 percent population rubicon: Can China urbanize to prosperity? Eurasian Geogr. Econ. 2012, 53, 63-86. [CrossRef]

155. Kennedy, J.J. From the tax-for-fee reform to the abolition of agricultural taxes: The impact on township governments in North-West China. China Q. 2007, 189, 43-59. [CrossRef]

156. Chen, C.; LeGates, R.; Fang, C. From coordinated to integrated urban and rural development in China's megacity regions. J. Urban Aff. 2019, 41, 150-169. [CrossRef]

157. Goodkind, D.; West, L.A. China's Floating Population: Definitions, Data and Recent Findings. Urban Stud. 2002, 39, 2237-2250. [CrossRef]

158. Han, R.; Wang, L. Challenges and Opportunities Facing China's Urban Development in the New Era. China Perspect. 2013, 2, 15-27. [CrossRef]

159. Yang, D.T.; Zhou, H. Rural-urban disparity and sectoral labour allocation in China. J. Dev. Stud. 1999, 35, 105-133. [CrossRef]

160. Liu, X.; Cao, G.Z.; Liu, T.; Liu, H.C. Semi-urbanization and evolving patterns of urbanization in China: Insights from the 2000 to 2010 national censuses. J. Geogr. Sci. 2016, 26, 1626-1642. [CrossRef]

161. Wang, C.G. A study of floating rural people's "semi-urbanization". Sociol. Stud. 2006, 5, 107-122. (In Chinese)

162. Gang, X. Need to Narrow Income Gap. China Daily. 16 September 2011. Available online: http://www. chinadaily.com.cn/cndy/2011-09/16/content_13712379.htm (accessed on 1 January 2020).

163. Boulter, J. China's Supply-Side Structural Reform. Global Economy, in Bulletin December Quarter 2018. Available online: https:/www.rba.gov.au/publications/bulletin/2018/dec/chinas-supply-side-structuralreform.html (accessed on 1 January 2020).

164. Chen, B.; Xu, H. Urban expansion and its driving force analysis using remote sensed data: A case of Xiamen City. Econ. Geogr. 2005, 25, 79-81. (In Chinese)

165. Deloitte. China Investment Guide: Opportunities in China's key Industries. 2019. Available online: https://www2.deloitte.com/us/en/pages/asian-services/articles/china-factors-a-guide-for-investingin-china.html (accessed on 1 January 2020).

166. Yip, G. China: The Global Hub for Knowledge-Based R\&D. 2017. Available online: https://www. imperial.ac.uk/business-school/blogs/ib-knowledge/china-global-hub-knowledge-based-rd/ (accessed on 1 January 2020). 
167. Boeing, P.; Mueller, E.; Sanbner, P. China's R\&D explosion-Analyzing productivity effects across ownership types and over time. Res. Policy 2016, 45, 159-176. [CrossRef]

168. Lin, G.C.S. The redevelopment of China's construction land: Practising land property rights in cities through renewals. China Q. 2015, 224, 865-887. [CrossRef] 